\begin{tabular}{|c|c|}
\hline $\begin{array}{c}\text { 2. To: (Receiving Organization) } \\
\text { Distribution }\end{array}$ & $\begin{array}{c}\text { 3. From: (Originating Organization) } \\
\text { Process Control }\end{array}$ \\
\hline $\begin{array}{l}\text { 5. Proj./Prog./Dept./Div.: } \\
\text { Tank 241-SY-101/Waste } \\
\text { Management/PC/Process } \\
\text { Engineering }\end{array}$ & $\begin{array}{l}\text { 6. Design Authority/ Design Agent/Cog. } \\
\text { Engr.: } \\
\begin{array}{lll}\text { J. M. Conner }\end{array}\end{array}$ \\
\hline
\end{tabular}

11. Receiver Remarks: 11A. Design Baseline Document? [] Yes $[X]$ No For release.

4. Related EDT No.:
N/A

7. Purchase Order No.:

$\mathrm{N} / \mathrm{A}$

9. Equip./Component No.:

$\mathrm{N} / \mathrm{A}$

10. System/Bldg./Facili ty: 241-SY-101

12. Major Assm. Dwg. No.:

N/A

13. Permit/Permit Application No.: $\mathrm{N} / \mathrm{A}$

14. Required Response Date: $05 / 12 / 99$

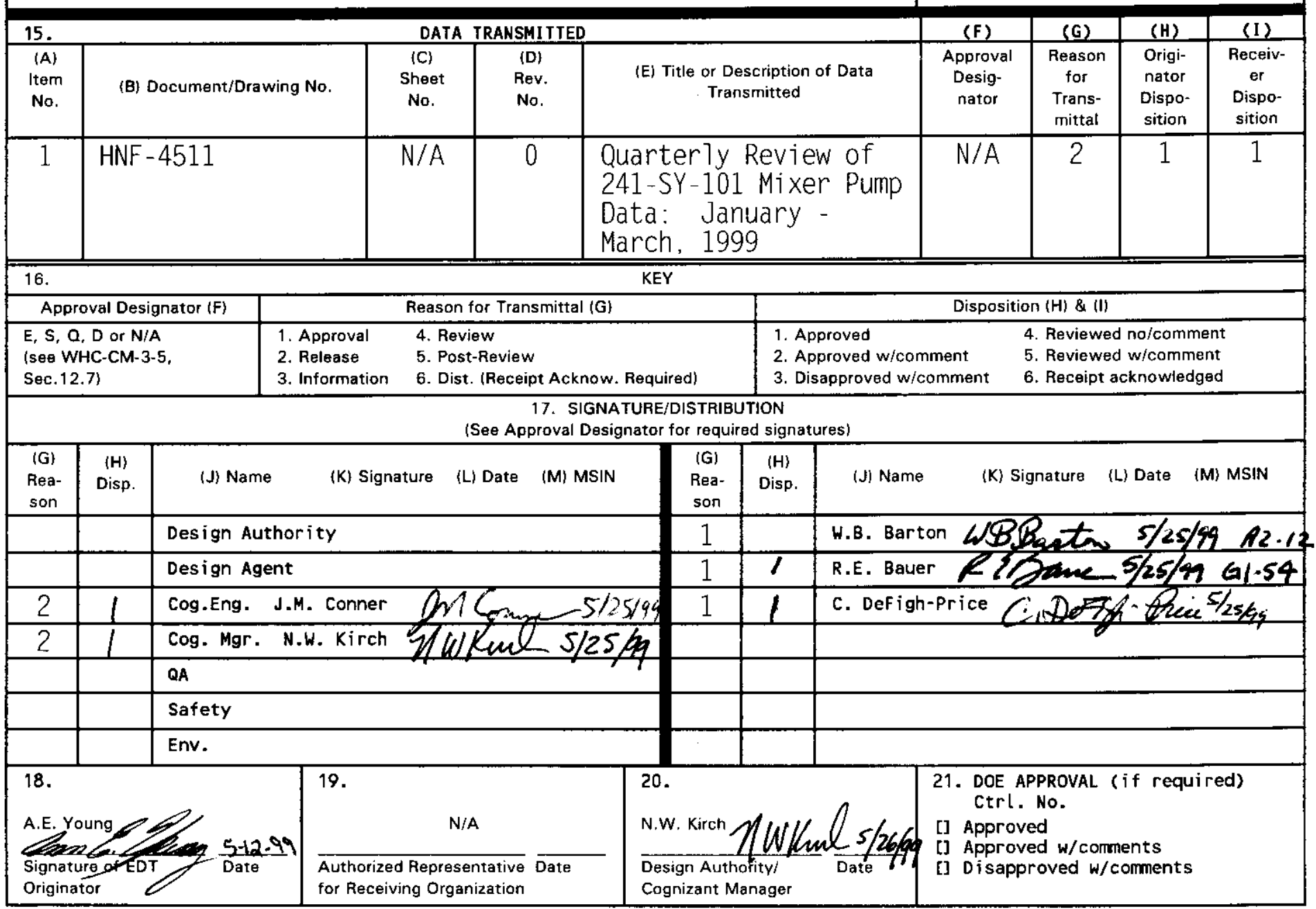

BD-7y00-172-2 (05/96) GEF097 


\section{Quarterly Review of 241-SY-101 Mixer Pump Data: January - March, 1999}

J. M. Conner, G. M. Koreski

Lockheed Martin Hanford, Corp., Richland, WA 99352

EDT/ECN: EDT-611468

Org Code: 7A150

B\&R Code: EW 3120074 Total Pages: 47

Key Words: Tank 241-SY-101, Tank SY-101, SY-101, SY Farm, Quarterly Review, Mixer Pump Data, Mixer Pump

Abstract: N/A

Enraf is a trademark of Enraf. Inc.

TRADEMARK DISCLAIMER. Reference herein to any specific comercial product, process, or service by trade name, trademark, manufacturer, or otherwise, does not necessarily constitute or imply its endorsement, recommendation, or favoring by the United States Government or any agency thereof or its contractors or subcontractors.

Printed in the United States of America. To obtain copies of this document, contact: Document Control Services, P.O. Box 950, Mailstop H6-08, Richland WA 99352, Phone (509) 372-2420;

Fax (509) 376-4989.
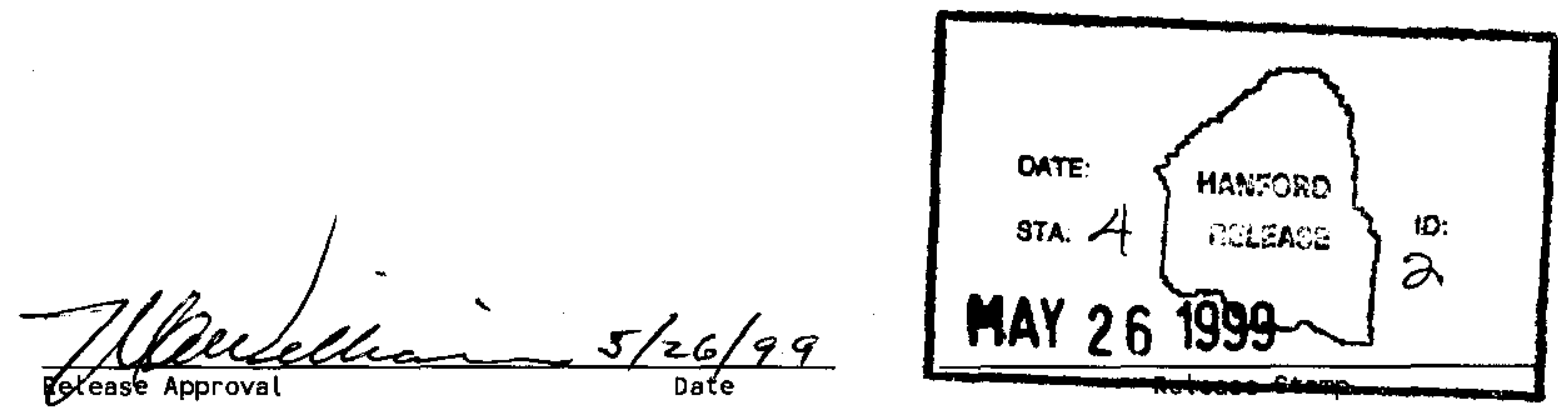

\section{Approved for Public Release}




\subsection{QUARTERLY SUMMARY}

This report presents data obtained on 241-SY-101 pump performance. The period covered is January 1 through March 31, 1999.

During the quarter:

- There were changes in pumping parameters. Both the pump volute pressure and amperage decreased during the quarter. It is not clear whether this was due to changes in waste properties (due to less solids or more entrained gas) or due to degradation of the pump.

- There was an indication of a 7.5-inch increase in the waste level at riser $1 \mathrm{~A}$, and an average growth rate of 0.082 inches per day.

- There was an indication of a 5.7-inch increase in the waste level at riser 1C. This riser was flushed with water several times, which would lower the level of the crust at this location.

- Gases continued to be released at less than the pre-pump installation baseline rate, indicating a decrease in the gas generation rate, or an increase in gas retention, or both. The release rate was about 78 percent of the rate in the previous few quarters, and only 34 percent of the generation rate calculated prior to mixer pump installation in 1993.

Key controls exist for waste temperature, gas concentration, pump parameters, and longterm waste behavior associated with the safe operation of the mixer pump that mitigates the buoyant displacement gas release event behavior of 241-SY-101. Table 1-1 compares the key controls and the current state of the waste as of March 31, 1999.

The pump was run 28 times between January 1 and March 31, 1999. All of the pump runs were intended to be normal 25-minute, 1000-rpm excavation runs performed to mix the waste and release gas. Because of the pump oil often reached the high temperature alarm setpoint of $190 \mathrm{~F}$, many of the runs were shortened (by as many as 8 minutes). This phenomenon was identified in November 1998, but got progressively worse over the quarter. The pump schedule was nominally three runs per week. However, core sampling activities interrupted the usual pump schedule several times during the quarter, resulting in less pump runs than normal. There is evidence that the pump is not operating the same as it has in previous years. Pump power and volute pressure have both been reduced. It is not clear whether this is a. result of pump degradation or whether the fluid parameters of the waste have changed (less solids or more entrained gas).

The Enraf level gauge in riser $1 \mathrm{~A}$ indicated a level increase of 7.5 inches. The estimated growth rate is 0.082 inches per day, which is slightly higher than the growth rate of 0.076 inches per day during the previous quarter. It appears that the level growth is due to gas being retained in or under the crust. A temperature validation probe at MIT $17 \mathrm{C}$ indicated that the crust is thickening and the level of settled solids may have increased slightly. The level growth phenomenon is discussed further in Section 7.0.

The gas chromatograph (GC) GC-3, was operational $89 \%$ of the time. GC-1 was 
operational $87 \%$ of the time. During the quarter, the calculated gas releases were $34 \%$ of the baseline generation rate prior to pump installation. The final run of the quarter, on March 31 , 1999 , was the $1030^{\text {th }}$ time the pump was operated since its installation in the tank. Hydrogen and nitrous oxide concentrations were slightly lower than in the previous quarter and much lower than in quarters before that. The average weekly hydrogen concentration dropped below $10 \mathrm{ppm}$ for the first time since the pump operations began.

Tank temperatures did not exhibit a drop towards seasonal lows in this Jan-Mar quarter as in previous years. In fact, temperatures in the tank continue to increase. The average waste temperature exceeded $120^{\circ} \mathrm{F}$ at MIT $17 \mathrm{C}$ for the first time since the pump operations began and was at $119.8^{\circ} \mathrm{F}$ at MIT $17 \mathrm{~B}$ at the end of the quarter. The average temperature at the end of the quarter was approximately $4{ }^{\circ} \mathrm{F}$ higher than at the same time last year.

Table 1-1. Key Controls

\begin{tabular}{|c|c|c|}
\hline Control & $\begin{array}{l}\text { Requirement for Normal } \\
\text { Pump Operation }\end{array}$ & Status as of $3 / 31 / 99$ \\
\hline Level & $\mathrm{N} / \mathrm{A}^{1}$ & $\begin{array}{l}\text { Riser } 1 \mathrm{~A}^{2}: 11.00 \mathrm{~m} \text { (432.9 in.) } \\
\text { Riser 1C: } 10.48 \mathrm{~m} \text { (412.7 in.) }\end{array}$ \\
\hline $\begin{array}{l}\text { Maximum Waste } \\
\text { Temperature }\end{array}$ & $<52.2^{\circ} \mathrm{C}\left(126^{\circ} \mathrm{F}\right)^{3}$ & $51.6^{\circ} \mathrm{C}\left(124.9^{\circ} \mathrm{F}\right)$ \\
\hline $\begin{array}{l}\text { Minimum Average } \\
\text { Waste Temperature }\end{array}$ & $>43.3^{\circ} \mathrm{C}\left(110^{\circ} \mathrm{F}\right)$ & $48.7^{\circ} \mathrm{C}\left(119.8^{\circ} \mathrm{F}\right)$ \\
\hline Hydrogen & $\begin{array}{l}\text { weekly average } \mathrm{H}_{2} \\
\text { concentration }>10 \text { ppm } \\
<7500 \text { ppm during pump run }\end{array}$ & $\begin{array}{l}\text { weekly average } \mathrm{H}_{2} \text { concentrations } \\
\text { ranged from } 9^{(4)} \text { to } 32 \mathrm{ppm} \\
<300 \text { ppm during pump runs }\end{array}$ \\
\hline $\begin{array}{l}\text { Long-Term Tank } \\
\text { Conditions }\end{array}$ & $\begin{array}{l}\text { any significant adverse } \\
\text { change }\end{array}$ & $\begin{array}{l}\text { level increase of } 0.082 \mathrm{in} . / \mathrm{day}^{(5)} \text {; } \\
\text { level growth is being evaluated } \\
\text { (LMHC 1998) } \\
\text { Tank temperature trends being } \\
\text { evaluated } \\
\text { Potential pump degradation being } \\
\text { evaluated }\end{array}$ \\
\hline
\end{tabular}

${ }^{1}$ Level controls were removed by Standing Order TWO-99-001 (LMHC 1998). For tank intrusive operations, the standing order requires a review of level data to ensure a change of $>0.5$ inches has not occurred in the previous $24 \mathrm{hrs}$.

${ }^{2}$ See Appendix A for a discussion of riser numbering.

${ }^{3}$ Raised from 125 to $126 \mathrm{~F}$ on $4 / 7 / 99$ by Test Review Group (TRG)

${ }^{4}$ Low hydrogen evaluated by TRG with the decision to continue pump operations as before

${ }^{5} \mathrm{Based}$ on linear regression of the daily level at riser $1 \mathrm{~A}$. The level growth data from riser $1 \mathrm{C}$ were not used because $1 \mathrm{C}$ was subjected to several flushes. 


\subsection{LEVEL}

The level at the end of the March quarter, according to the Enraf level gauge in riser $1 \mathrm{~A}$, was $11.00 \mathrm{~m}$ (432.9 in.), indicated a level increase of 7.5 inches for the quarter. The Enraf in riser $1 \mathrm{C}$ increased 5.70 inches to $10.48 \mathrm{~m}$ (412.72 in). The level increases are discussed further in Section 6.0.

For the period from December 31 to March 31, 1998, the average difference (offset) between the two Enrafs was $48.0 \mathrm{~cm}$ (18.9 in.). This offset is 2.3 inches bigger than last quarter. The larger offset appears to be a result of flushes of the riser $1 \mathrm{C}$ level gauge. Figure 1 shows the Enraf-1C and Enraf-1A waste level measurements over the last year. Figure 2 shows the $1 \mathrm{~A}$ level and the 120-day rolling average for the growth rate at riser $1 \mathrm{~A}$. The average growth rate has increased from about $0.020 \mathrm{in} /$ day at the beginning of 1998 to $0.082 \mathrm{in} / \mathrm{day}$ at the end of March 1999.

\subsection{TEMPERATURES}

The mixed slurry layer had an average temperature of $48.8^{\circ} \mathrm{C}\left(119.8^{\circ} \mathrm{F}\right)$ on March 31, 1999, based on Data Acquisition and Control System (DACS) readings from MIT17B. The mixed slurry layer average temperature was $49.1^{\circ} \mathrm{C}\left(120.4{ }^{\circ} \mathrm{F}\right)$ on March 31, 1999, based on DACS readings from MIT-17C. These average waste temperatures are above the minimum control temperature of $43.3^{\circ} \mathrm{C}\left(110^{\circ} \mathrm{F}\right)$. The maximum temperature from the current temperature profile (DACS readings) is $51.6^{\circ} \mathrm{C}\left(124.9^{\circ} \mathrm{F}\right)$ which is below the maximum control temperature of $52.2^{\circ} \mathrm{C}\left(126^{\circ} \mathrm{F}\right)$. Figure 3 shows the vertical temperature profiles at MIT-17B and -17C as of March 31, 1999.

Figure 4 shows the bulk average waste temperatures since January 1994 . Temperatures at both MITs have deviated from the seasonal trend, and are now approximately $4{ }^{\circ} \mathrm{F}$ hotter than at the same time last year. Previously, the maximum temperature had been reached by the end of the December quarter and the temperatures trended downward throughout the first quarter. Tank temperatures actually increased significantly during the first quarter of 1999 . This behavior is being monitored. Possible reasons for the increased temperature are discussed in Section 7.

\subsection{GASES}

There were no unexpected large gas releases during the quarter. Gas continued to be released at less than the pre-pump installation baseline rate, consistent with past quarters. However, the rate of release is much lower than in previous quarters. The weekly average hydrogen concentration dropped below $10 \mathrm{ppm}$ once during the quarter. Table 4-1 lists this quarter's monthly average gas concentrations. Table 4-2 compares this quarter's average gas concentrations with past quarterly averages. Hydrogen and nitrous oxide concentrations are lower than in previous quarters. 
HNF-4511, Rev. 0

Table 4-1. Gas Monthly Average Concentrations

\begin{tabular}{||l|c|c|c|}
\hline Gas (Instrument) & \multicolumn{3}{|c|}{ Monthily Average Concentrations (ppm) } \\
\hline \hline & $1 / 1 / 99-1 / 31 / 99$ & $2 / 1 / 99-2 / 28 / 99$ & $3 / 1 / 99-3 / 31 / 99$ \\
\hline Hydrogen (GC-1) & 16 & 16 & 17 \\
\hline Hydrogen (GC-3) & 24 & 16 & 17 \\
\hline Ammonia (FTIR) & 53 & 54 & 61 \\
\hline $\begin{array}{l}\text { Nitrous Oxide } \\
\text { (FTIR) }\end{array}$ & 17 & 12 & 12 \\
\hline
\end{tabular}

Table 4-2. Quarterly Average Concentrations

\begin{tabular}{|l|c|c|c|}
\hline Gas (Instrument) & $7 / 1 / 98-9 / 30 / 98$ & $10 / 1 / 98-12 / 31 / 98$ & $1 / 1 / 99-3 / 31 / 99$ \\
\hline Hydrogen (GC-1) & 39 & 21 & 16 \\
\hline Hydrogen (GC-3) & 33 & 22 & 19 \\
\hline $\begin{array}{l}\text { Ammonia (FTIR) } \\
\text { (conc. varies seasonally) }\end{array}$ & 54 & 48 & 56 \\
\hline Nitrous Oxide (FTIR) & 24 & 18 & 14 \\
\hline
\end{tabular}

Figures 5, 6, and 7 show the hydrogen concentrations measured by GC-3 for each of the three months of this quarter. The hydrogen concentration in the dome reached as high as 295 ppm during the pump run on March 31, 1999. Peaks seemed to increase significantly towards the end of March. Notable natural releases are indicated on January 16, February 6, and March 2.

Figures 8,9 , and 10 show the GC-1 measured hydrogen concentrations for January through March 1999. Based on this instrument, the hydrogen concentration in the dome reached as high as $258 \mathrm{ppm}$ during the pump run on March 31, 1999. Figures 11, 12, and 13 show the Fourier transform infrared spectrometer (FTIR) measured concentrations of ammonia and nitrous oxide for each month. Nitrous oxide peaks following pump runs were also significantly higher at the end of March.

Figure 14 shows the calculated weekly total gas releases from January 1, 1994, to March 28,1999 . Daily total gas release volumes are calculated by integrating the product of the hydrogen concentration (GC-1) and the vent header flow rate and dividing by an assumed hydrogen fraction of 0.29 in the tank gas. These daily gas release volumes are summed on a weekly basis. From January 3, 1999, to March 28, 1999, the average release was about $6.8 \mathrm{~m}^{3}$ $\left(239 \mathrm{ft}^{3}\right)$ per week compared with the pre-pump installation baseline rate of $19.8 \mathrm{~m}^{3}\left(700 \mathrm{ft}^{3}\right)$ per week. A reduction in total gas release rate over time has been observed since the pump was installed in 1993. The release rate for this quarter is 78 percent of the previous quarter's calculated release rate. 
An overall release rate can also be derived from estimates of gas generation and retention. The average generation/release rate prior to pump installation was $19.8 \mathrm{~m}^{3}\left(700 \mathrm{ft}^{3}\right)$ per week. The reduction in the generation rate can be calculated by assuming the key radionuclide in the waste is ${ }^{137} \mathrm{Cs}$. In the 6 years since the pump was installed, the ${ }^{137} \mathrm{Cs}$ concentration has dropped 13 percent because of radioactive decay. Assuming a linear relationship between the ${ }^{137} \mathrm{Cs}$ concentration and the gas generation rate, the current generation rate would be lower by $2.6 \mathrm{~m}^{3}$ $\left(91 \mathrm{ft}^{3}\right)$ per week, or $17.2 \mathrm{~m}^{3}\left(609 \mathrm{ft}^{3}\right)$. The average level rise for the quarter $(0.082 \mathrm{in} /$ day from ENRAF in riser 1A) corresponds to $7.7 \mathrm{~m}^{3}\left(274 \mathrm{ft}^{3}\right)$ of retained gas per week, assuming the gas is retained in the crust at 1.3 times atmospheric pressure. Subtracting this retention estimate from the generation estimate $17.2 \mathrm{~m}^{3}\left(609 \mathrm{ft}^{3}\right)$ yields an estimated release rate of $9.5 \mathrm{~m}^{3}\left(335 \mathrm{ft}^{3}\right)$ per week. This calculation is higher than the $6.8 \mathrm{~m}^{3}\left(239 \mathrm{ft}^{3}\right)$ per week derived from the $\mathrm{H}_{2}$ release rate. Other than measurement errors, possible reasons for the discrepancy include that the decrease in the generation rate is greater, that the assumed pressure is too low, or that the $\mathrm{H}_{2}$ gas fraction of the released gas is higher than it was previously.

Figure 15 shows the weekly volumes of ammonia and nitrous oxide released from January 1, 1994 to March 28, 1999. The seasonal variation of ammonia release is evident in the figure, although the latest upswing has been higher than the peak weekly values from previous years. A general decrease in nitrous oxide is also apparent. Figures 16, 17, and 18 show the weekly concentrations of hydrogen, nitrous oxide, and ammonia for the same period. The average $\mathrm{N}_{2} \mathrm{O} / \mathrm{H}_{2}$ ratio calculated from this quarter's weekly averages is 0.72 . Three years ago, from January to March 1996, the ratio was about 1.3 .

\subsection{PUMP PARAMETERS}

The pump was run 28 times this quarter between January 1 and March 31, 1999. The schedule was typically three 25 -minute, 1000 -rpm excavation runs per week at the 12 standard orientations. However, core sampling activities often restricted the pumping schedule several times because of the restriction that the pump not be run with the drill string in the waste. There were several stretches of approximately 1 week where the pump was not run.

Beginning in November 1998, the pump oil high temperature alarm, set at $190^{\circ} \mathrm{F}$, would sometimes go off towards the end of pump runs. This trend continued in this quarter. Pump run durations varied from 17 to 25 minutes. The run length was affected by the time since the previous pump run. Shorter invervals between pump runs tended to result is shorter runs because the oil temperature had not cooled enough prior to the second run.

Changes in mixer pump performance were identified during the quarter. Both pump power and volute pressure decreased significantly during the quarter. Figure 19 depicts 4 graphs of pump performance data at pump angles of 275 degrees (i.e., the second pump nozzle at 95 degrees). The first parameter is power (current $x$ voltage $\mathrm{x}$ square root of 3 ), which seemed to increase sharply about a year ago and then steadily decline. The second parameter is volute pressure, which has tailed off significantly in the last 6 months. No trend is evident from the pump pressure drop (volute pressure - discharge pressure) graph. The intake temperature graph mirrors the tank average temperature graph (showing the recent increase in the tank temperature). 
Data for a typical run during this quarter, on March 31, 1999, are presented in Figures 20 26. Figures 20 and 21 show nozzle pressures on a coarse and fine scale. Figure 22 shows volute pressure; Figure 23 shows pump current, voltage, and speed on a coarse scale; and Figures 24, 25 , and 26 show the same data on a finer scale. Figure 27 shows the motor oil heat-up during the run. Pump current and volute pressure have changed significantly since the previous quarter.

The reason for the decrease in pump power and discharge pressure is unclear. It may be that the viscosity of the fluid has decreased, or that the density has decreased (due to fewer solids or more gas).

Although the oil temperature rise during pump runs has remained consistent, the oil cooling rate was identified as an issue in late December. The oil cooling rate is much slower than it was several months ago (Figure 28). The most likely explanations for the different cooling rate are that the bulk waste temperature is higher, leading to reduced heat transfer, or that a small hole in the top of the pump housing which previously allowed the hot waste around the pump to convect away, has become plugged. This issue is being evaluated. There has been no indication of moisture in the motor oil. A sensor is located in the pump sump specifically for detecting water in the motor oil.

\subsection{CORE SAMPLING ACTIVITIES}

Core sampling activities were initiated in accordance with Conner (1998). The last two core samples (of a total of three) were completed during the quarter. The 222-S Laboratory reported results from two composite samples from the first core during the quarter (Steen 1999). Final analytical results will be referenced in a future quarterly report.

\subsection{WASTE BEHAVIOR}

As discussed in Section 2.0, the Enraf level gauge in riser 1A showed an increase of 7.5 inches during the quarter. This indicates a slight acceleration in growth over the previous quarter ( 7.0 inches for Oct. - Dec.). The growth rate at riser $1 \mathrm{~A}$ was $0.082 \mathrm{in}$. per day based on a linear regression of the daily level data. This rate is about the same as the pre-pump baseline growth rate (0.08 in. per day).

An adverse trend towards build-up of nonconvective solids appears to be occurring. Figure 29 shows the bottom four thermocouples of MIT-17B during the pump run on March 21, when a nozzle was pointed in the direction of this MIT ( 97 degrees). The bottom thermocouple shows very little response to the jet. This indicates an undisturbed layer of greater than 4 inches thick at a distance of 8.60-m (28.2 ft) from the pump at this location. From 1994 until November 1998 , the bottom thermocouple responded during the pump run and reached the bulk slurry temperature. The $12 / 98$ and $1 / 99$ pump runs at this angle nearly reached the bulk slurry temperature. The poor response in March is similar to the response in February.

Figure 30 shows the MIT-17C bottom four thermocouples during the pump run of March 
15,1999 , when a nozzle was pointed in the direction of the MIT (28 degrees). The data indicate an undisturbed solids layer somewhat higher than 16 inches. The thermocouple at the 16-inch level responds, but does not reach the bulk slurry temperature. The MIT is $9.32 \mathrm{~m} \mathrm{(30.6)}$ feet from the pump, or 2.4 feet further than MIT 17B. Pump runs at this angle occasionally excavated solids down to the 16-inch level, but not in the last year. The pump seems to be slightly less effective at excavating the settled solids at the MITs. This behavior is being monitored closely.

According to the MIT validation probe temperature profiles, an increase in crust thickness is occurring. The crust may be as much as $3.3 \mathrm{~m}$ (130 in) thick based on the latest validation probe in MIT 17B (Figure 31). This interpretation is somewhat subjective. The crust thickness was reportedly $1 \mathrm{~m}$ (40 in.) thick in 1993 and for several years thereafter, and was estimated at $1.6 \mathrm{~m}$ (63 in) 6 months ago. Figure 31 also shows the validation probe from a year ago (3/24/98) in MIT 17B. There are major differences from last year's profile: the crust is now thicker, the settled solids layer appears thicker, and the convective layer is hotter by about $4.5^{\circ} \mathrm{F}$. The increase in temperature may be due to the thicker crust providing more insulation, limiting heat loss to the dome space.

The gas volumes calculated from the VFI data (Stewart et al. 1998), combined with a hydrostatic model for crust buoyancy, accurately reflect the waste level. This confirms that the SY-101 level growth is mainly due to gas accumulation in the crust (Stewart et al. 1998). A large buoyant displacement is not credible given the current configuration of the waste. The settled solids layer in the tank no longer stores enough gas to cause a large rollover.

In summary, many changes have been observed in the tank recently. The level growth issue was identified to be a significant problem over a year ago. The growth rate has accelerated to a current level of 0.082 inches per day, near the level growth rate prior to mixer pump installation. The level growth has been attributed to an increase in the amount of gas stored in the crust. The bulk slurry appears to be relatively free of gas voids. The crust thickness has increased significantly. The settled solids may have increased slightly and are not as readily excavated by the pump. The hydrogen dome concentration and release rates have dropped recently, as has the peak hydrogen concentrations following pump runs (although this trend appeared to be reversing at the end of March). This is consistent with a thicker crust providing more resistance to gas migration. The nitrous oxide concentrations and release rates have been trending downward for at least two years. The ammonia concentration has been generally higher recently. Finally, the bulk waste temperature is hotter than it has been for at least 4 years. The Test Review Group (TRG) will continue to monitor the tank parameters and determine what changes (if any) to pump operations should occur.

\subsection{OTHER PARAMETERS}

The thermocouples below the annulus between the primary and secondary tanks were checked early in the quarter and a significant decrease noted. It was determined that this was caused by an unintentional increase in the annulus ventilation rate. The valve controlling the flow was reset and the flow returned to the previous rate. A graph of the temperature in the concrete below the secondary tank is shown in Figure 32. An increase in the annulus flow rate 
would lead to additional cooling of the waste, and may be responsible for the poorer excavation noted at MIT 17B (see discussion in Section 7).

Neutron and gamma scans in the MITs began in February. These techniques have been used in single-shell tanks to determine the interstitial liquid level and other waste features. It was hoped that the neutron scans in particular could discern features of the crust and interstitial liquid level much more accurately than the MIT profiles and quarterly MIT temperature validations. Although these techniques are still experimental in SY-101, preliminary results comparing neutron scans in February and March are shown in Figure 33. The results are very similar, and indicate a slight increase in the surface level. Some changes in the crust may also be indicated although without additional information it is difficult to interpret the changes. Further development of these scanning techniques is ongoing.

There were no other unexpected changes in the other tank parameters that were monitored for changes in waste behavior. Figure 34 shows the tank pressure and vent header flow rate histories. The pressure and flow rate were normal for the quarter. Figure 35 shows the vent header and atmospheric relative humidity histories. The water balance between ambient and vent header humidity indicates that during the quarter the waste gained about 1.8 gallons of water per day. Figure 36 shows the vent header and atmospheric temperatures during the quarter. Figure 37 compares the tank surface level with 1/atmospheric pressure. The measurement range for the ENRAF in riser $1 \mathrm{~A}$ was changed and the ENRAF returned to automatic level measurements in mid-March. This feature had been out of service since December when the surface level reached the previous setpoint of 425 inches.

\section{REFERENCES}

Conner, J. M., 1998, Push Mode Core Sampling and Analysis Plan for Double-Shell Tank 241SY-101, HNF-3375, Rev. 0, Lockheed Martin Hanford Corporation, Richland, Washington.

LMHC, 1998, Waste Surface Level Change in Tank 241-SY-101, Unreviewed Safety Question TF-97-0975, Rev. 2, Lockheed Martin Hanford Corporation, Richland, Washington.

Steen, F. H., “Compatibility Analyses Results for Tank 241-SY-101 Core Composites," Letter WMH-9951091 to K. M. Hall, February 24, 1999.

Stewart, C. W., J. M. Alzheimer, G. Chen, and P. A. Meyer, 1998, In Situ Void Fraction and Gas Volume in Hanford Tank 241-SY-101 as Measured with the Void Fraction Instrument, PNNL-12033, Pacific Northwest National Laboratory, Richland, Washington. 
HNF-4511, Rev. 0

\section{APPENDIX A}

\section{RISER NUMBERING}

This document continues to use the historical riser numbers assigned when the tank was designed. A drawing was recently released (H-14-010531) which changed the riser numbering of tank 241-SY-101. The table below lists the old and new riser numbers for risers that are used for monitoring or sampling.

\begin{tabular}{|c|c|c|}
\hline 1C & 001 & En \\
\hline $1 \mathrm{~A}$ & 002 & Enraf \\
\hline $4 \mathrm{~A}$ & 006 & Spare \\
\hline $11 \mathrm{~B}$ & 011 & Spare \\
\hline $11 \mathrm{~A}$ & 012 & Spare \\
\hline $17 \mathrm{~B}$ & 018 & MIT \\
\hline $17 \mathrm{C}$ & 019 & MIT \\
\hline $22 \mathrm{~A}$ & 021 & Gas Monitoring \\
\hline $23 \mathrm{~A}$ & 022 & Spare \\
\hline
\end{tabular}




\section{Figure 1. Tank 241-SY-101 Surface Level}

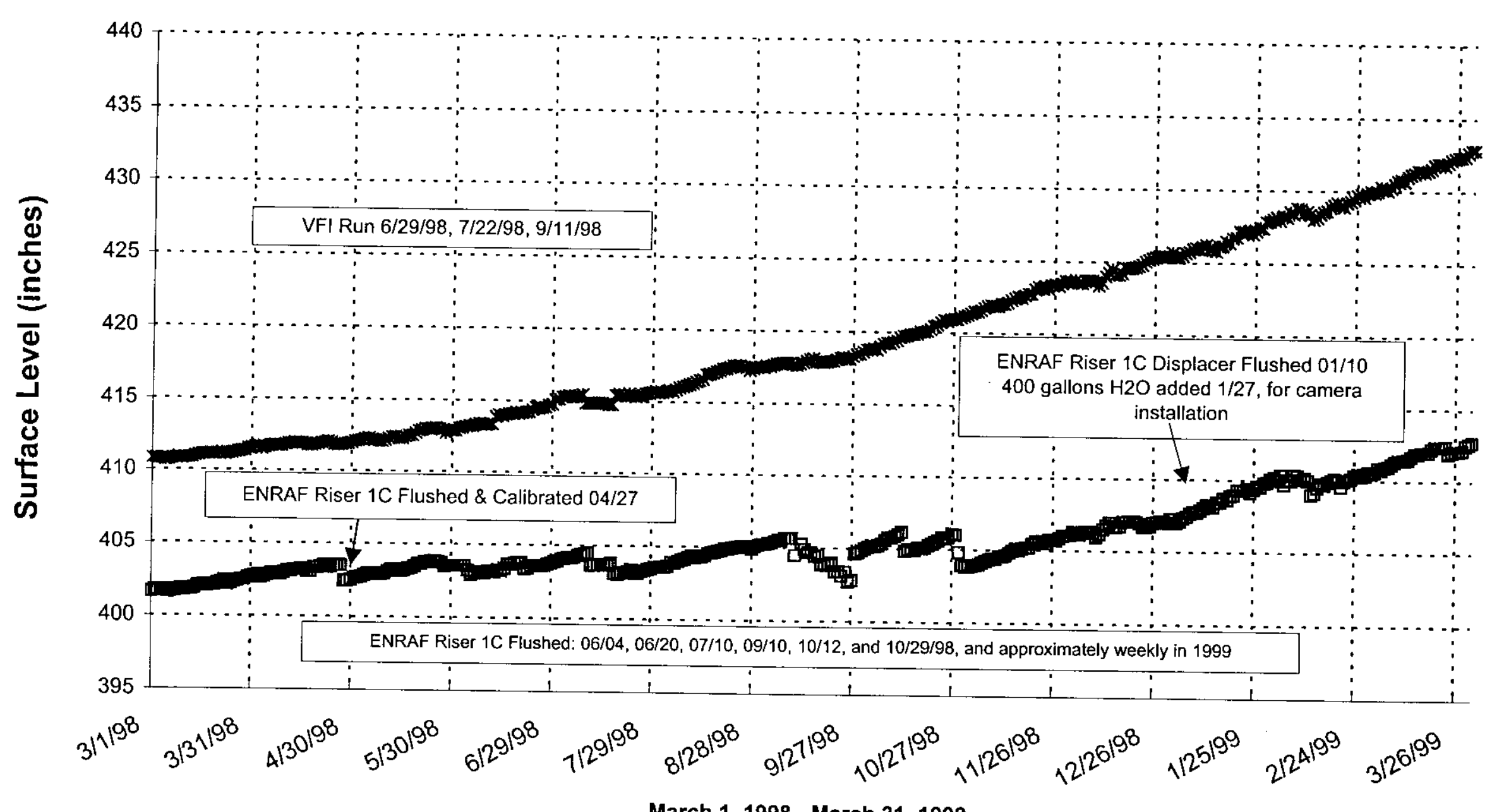

March 1, 1998 - March 31, 1999

a ENRAF - 1C $\rightarrow$ - ENRAF - 1A 
Figure 2. Riser 1A (002) Level and 120 Day Level Change

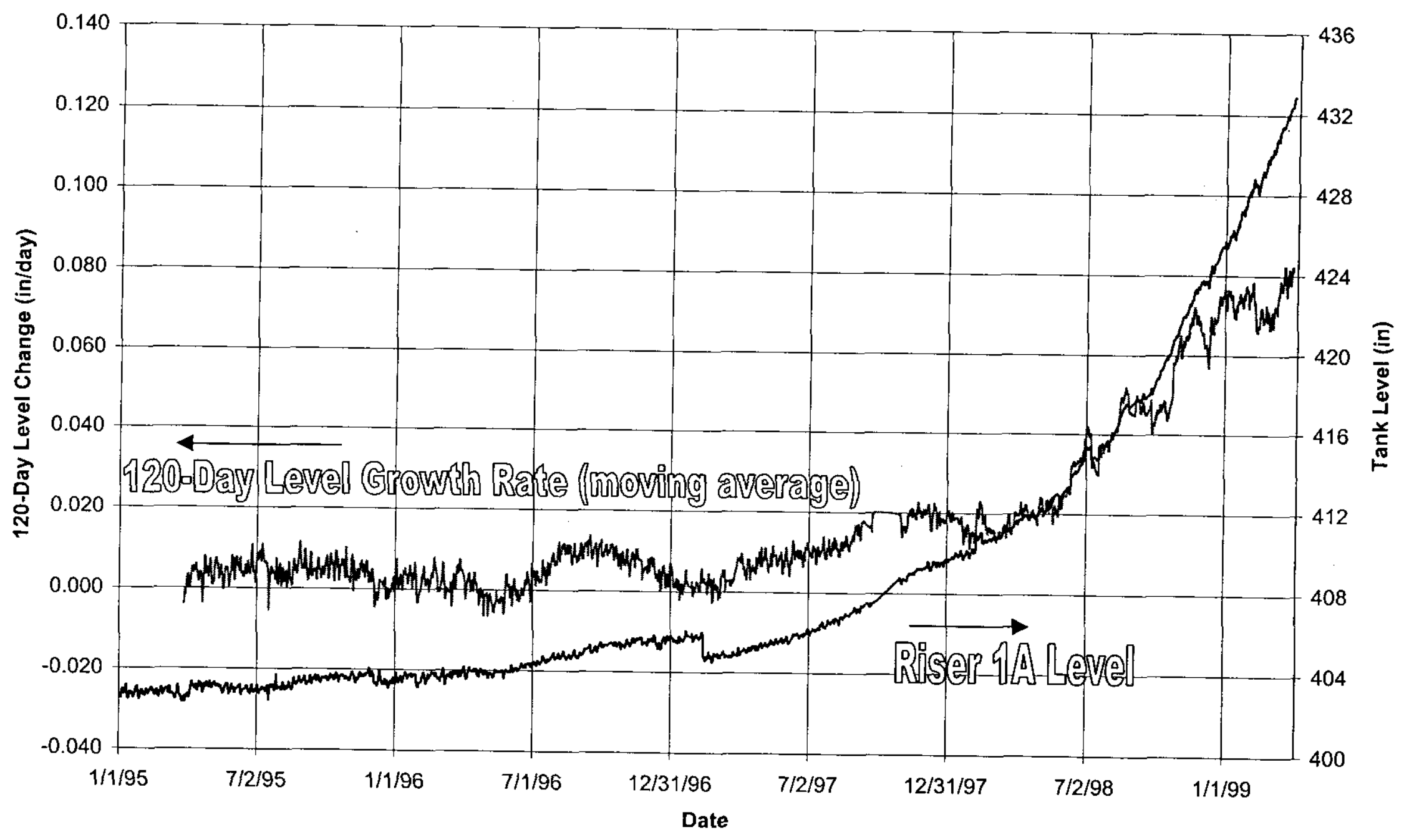


Figure 3. Tank 241-SY-101 Temperature Profile

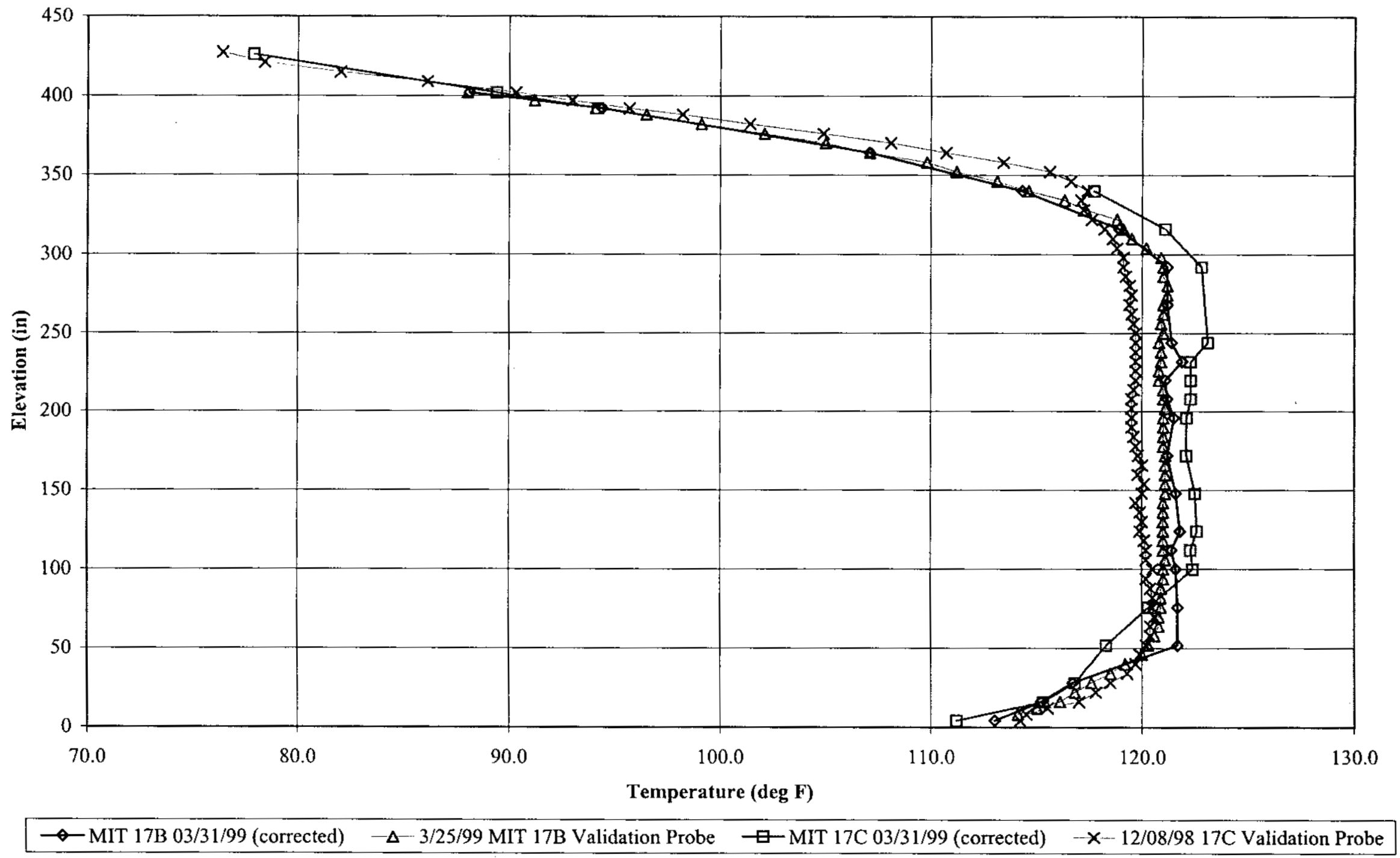




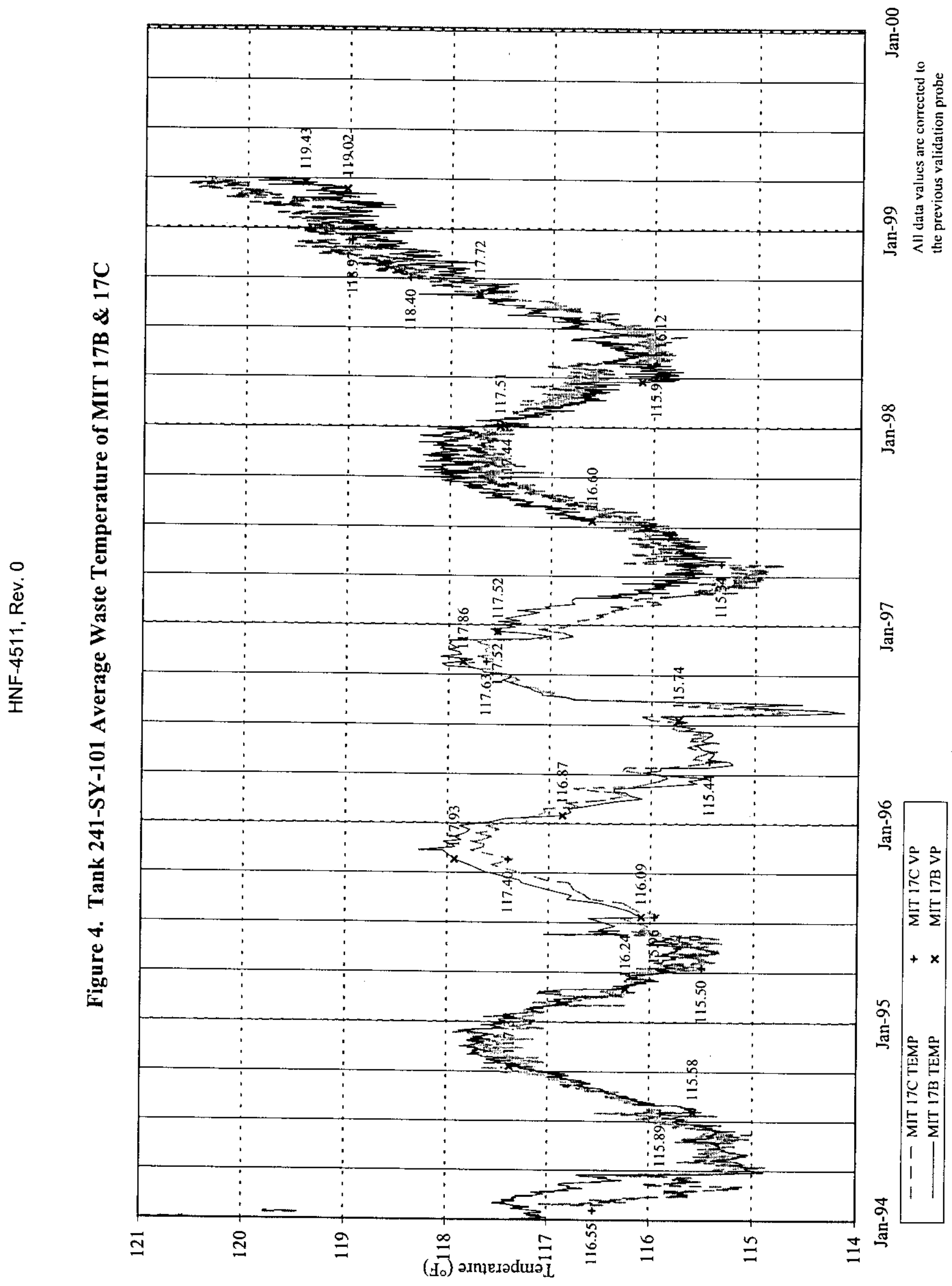

$\frac{m}{\frac{\pi}{0}}$ 
Figure 5. 241-SY-101 Gas Chromatograph 3 (GC-3) for January, 1999

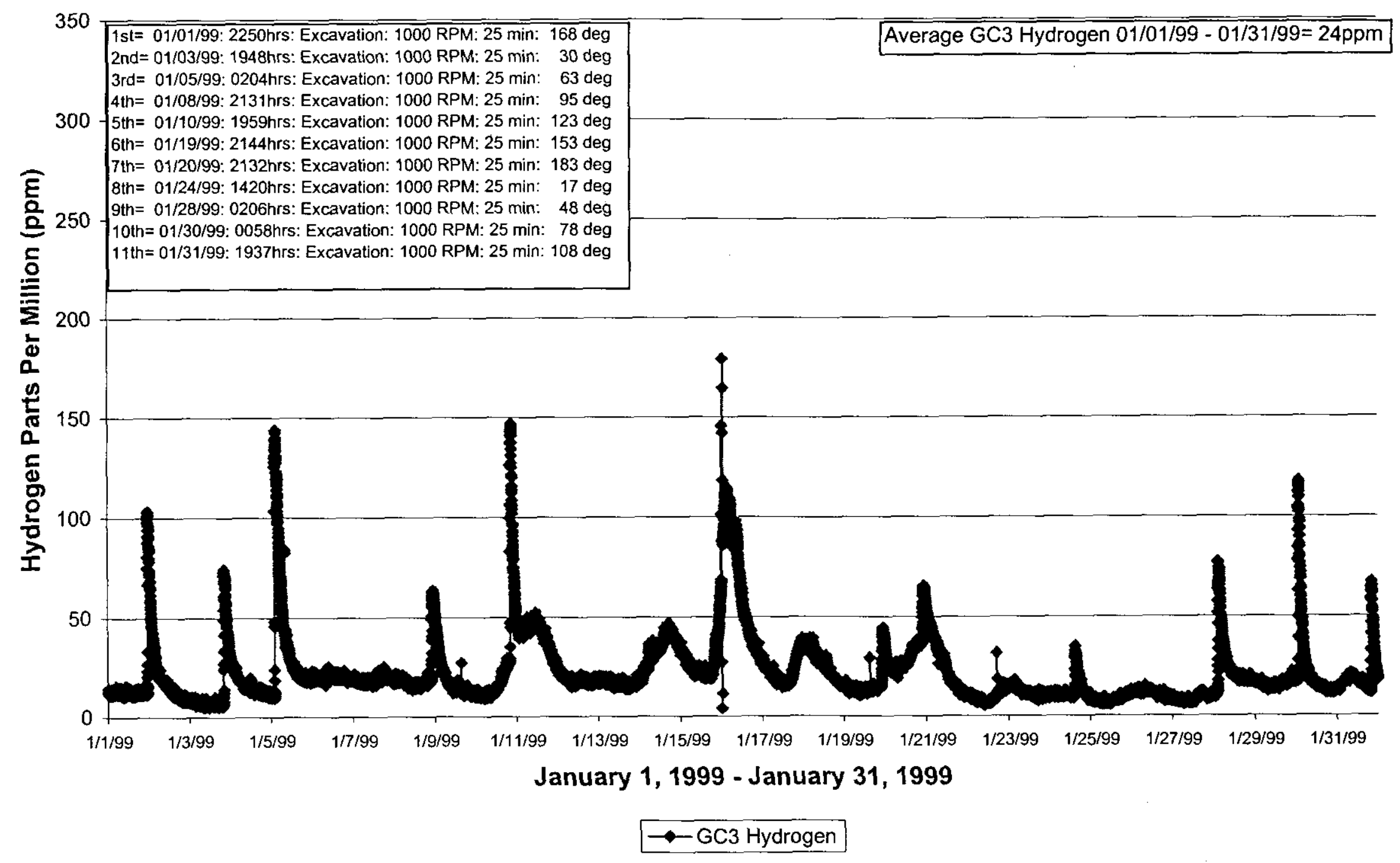


Figure 6. 241-SY-101 Gas Chromatograph 3 (GC-3) for February, 1999

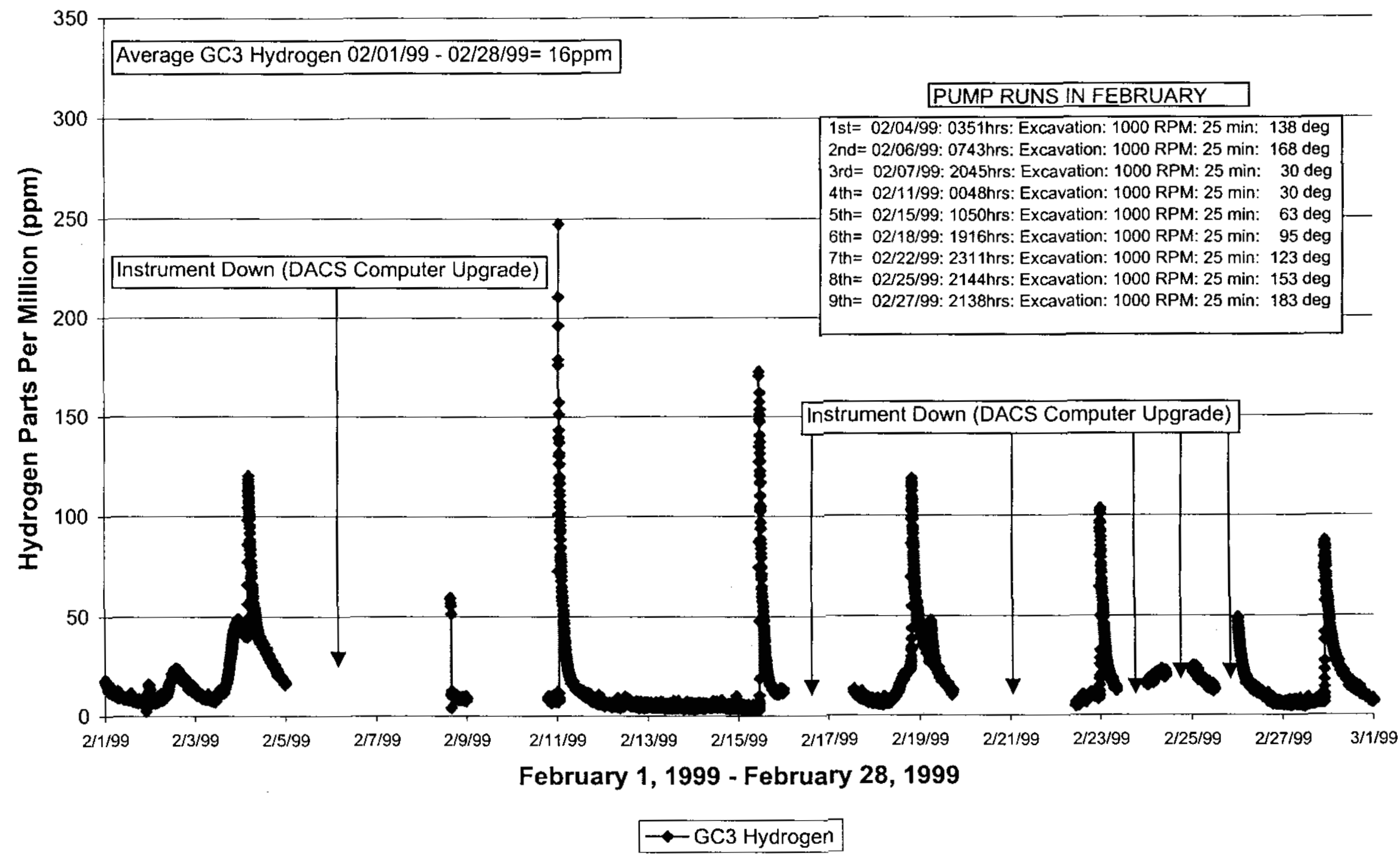

Page 15 
Figure 7. 241-SY-101 Gas Chromatograph 3 (GC-3) for March, 1999

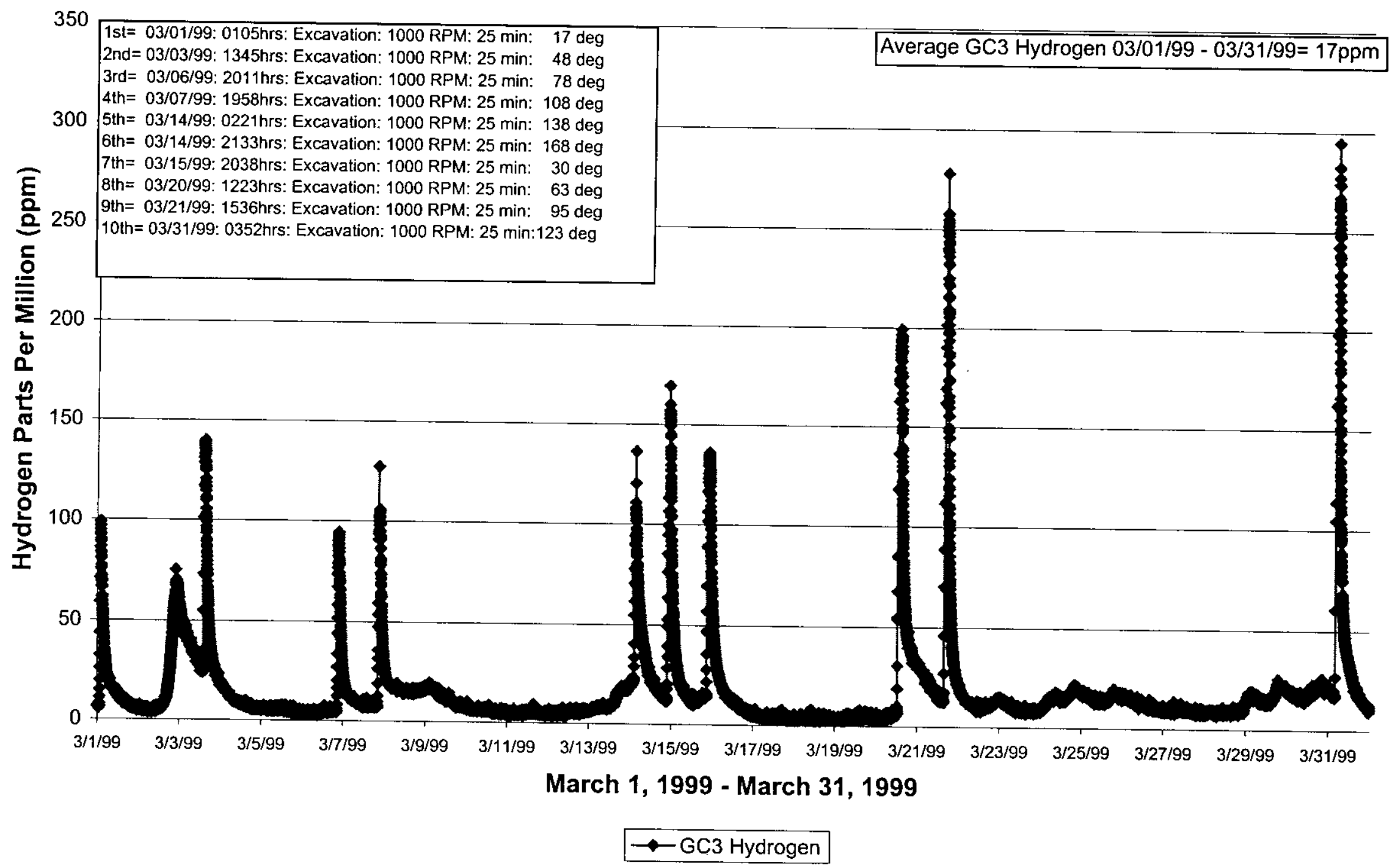

Page 16 
Figure 8. Tank 241-SY-101 Gas Chromatograph 1 (GC-1) Hydrogen for January, 1999

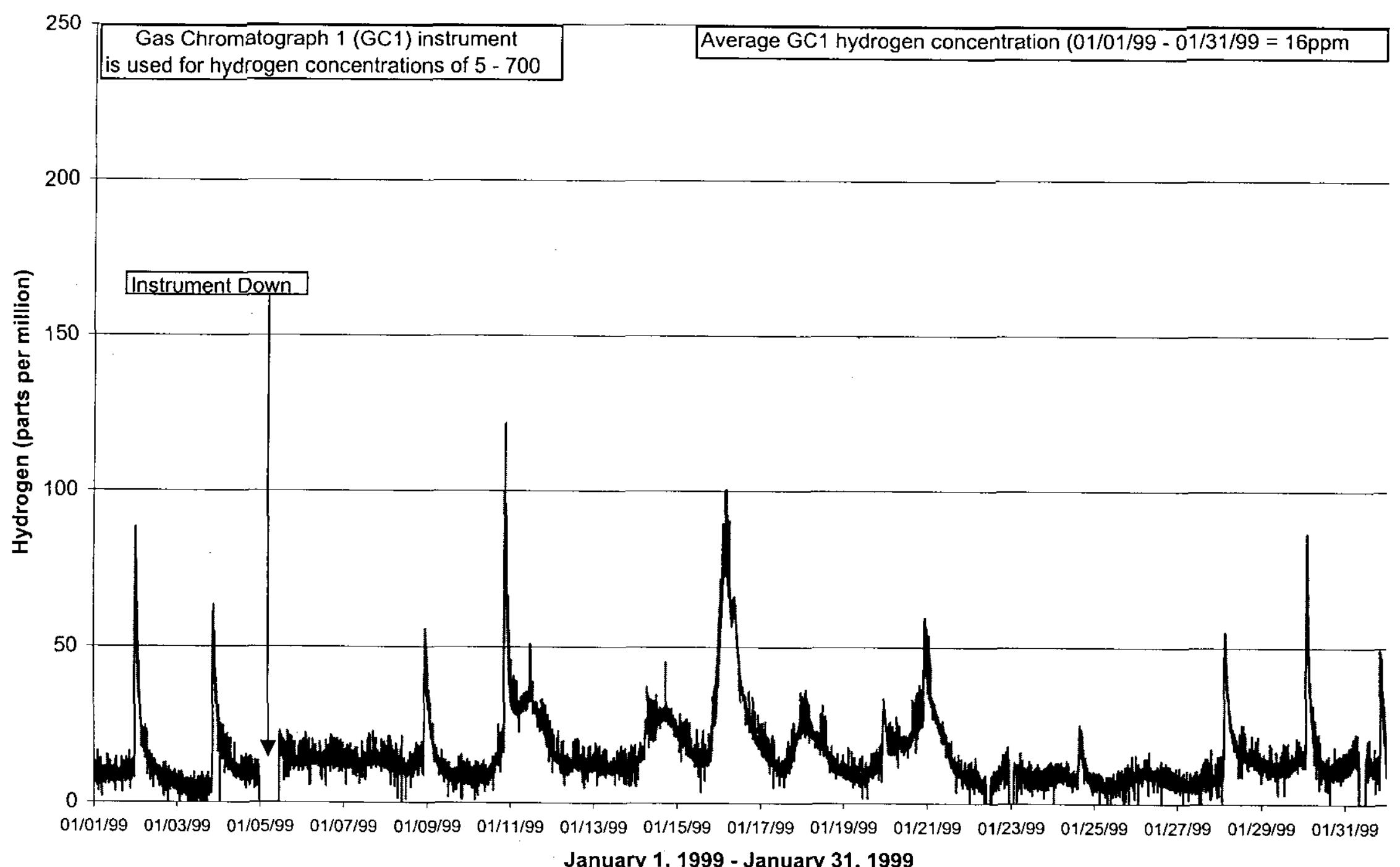


Figure 9. Tank 241-SY-101 Gas Chromatograph 1 (GC-1) Hydrogen for February, 1999

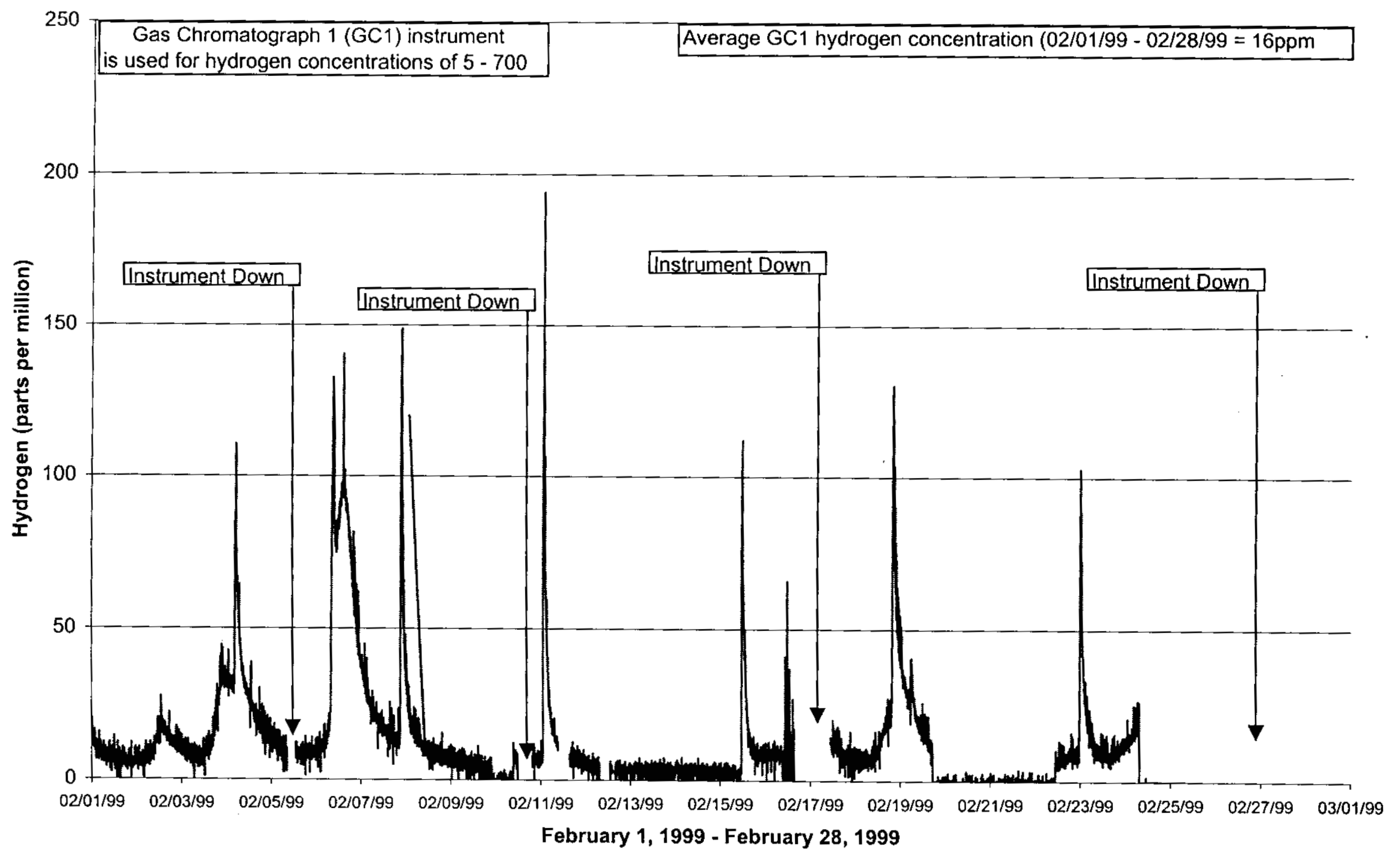


Figure 10. Tank 241-SY-101 Gas Chromatograph 1 (GC-1) Hydrogen for March, 1999

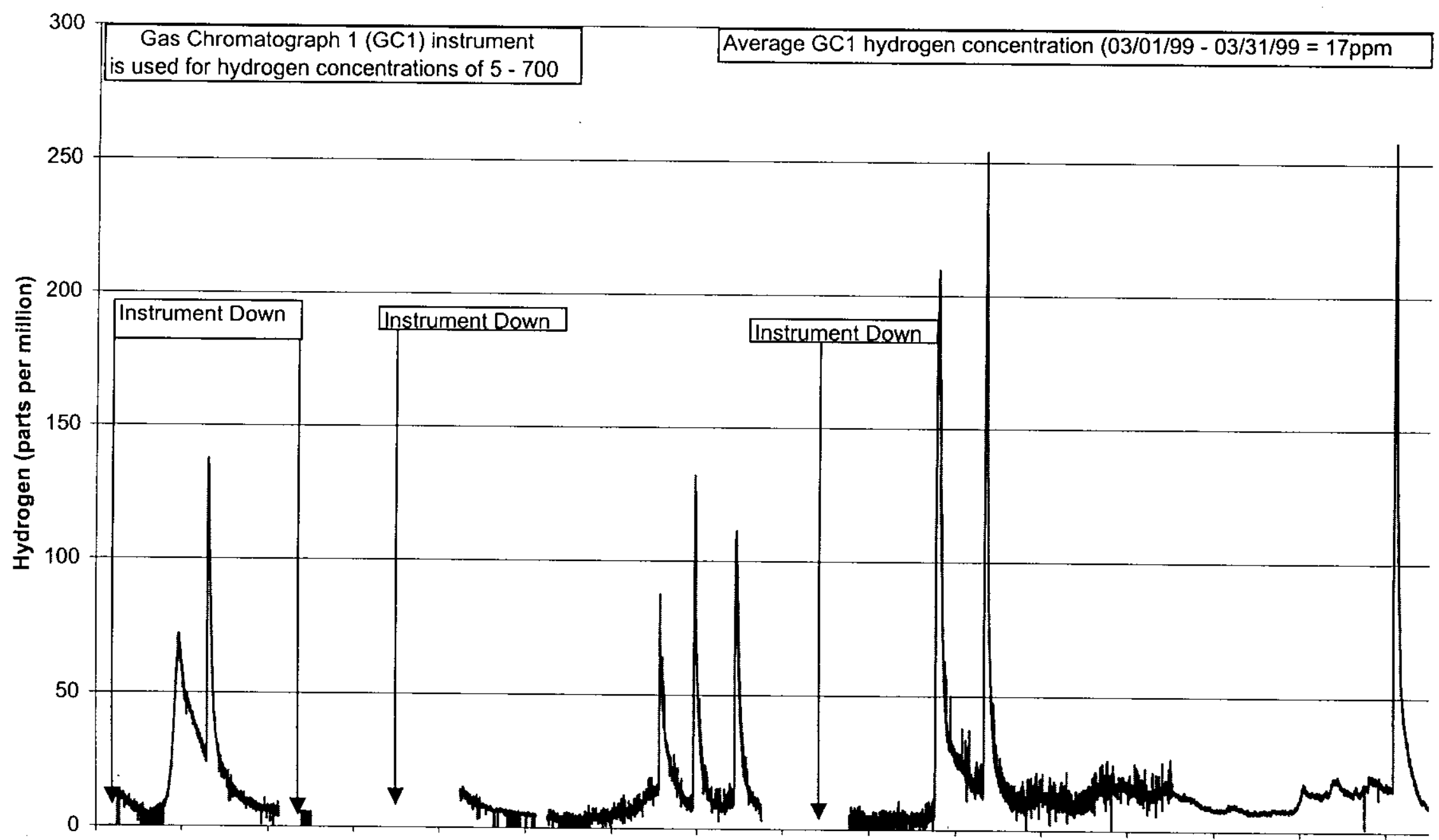

$\begin{array}{lllllllllllllllll}03 / 01 / 99 & 03 / 03 / 99 & 03 / 05 / 99 & 03 / 07 / 99 & 03 / 09 / 99 & 03 / 11 / 99 & 03 / 13 / 99 & 03 / 15 / 99 & 03 / 17 / 99 & 03 / 19 / 99 & 03 / 21 / 99 & 03 / 23 / 99 & 03 / 25 / 99 & 03 / 27 / 99 & 03 / 29 / 99 & 03 / 31 / 99\end{array}$ March 1, 1999 - March 31, 1999 


$$
\mathrm{OZN} \rightarrow-\mathrm{HHN} \longrightarrow
$$

\section{$666 \downarrow$ ' $ا \varepsilon$ Nienuer - $666 l$ ' $L$ Kuenuer}

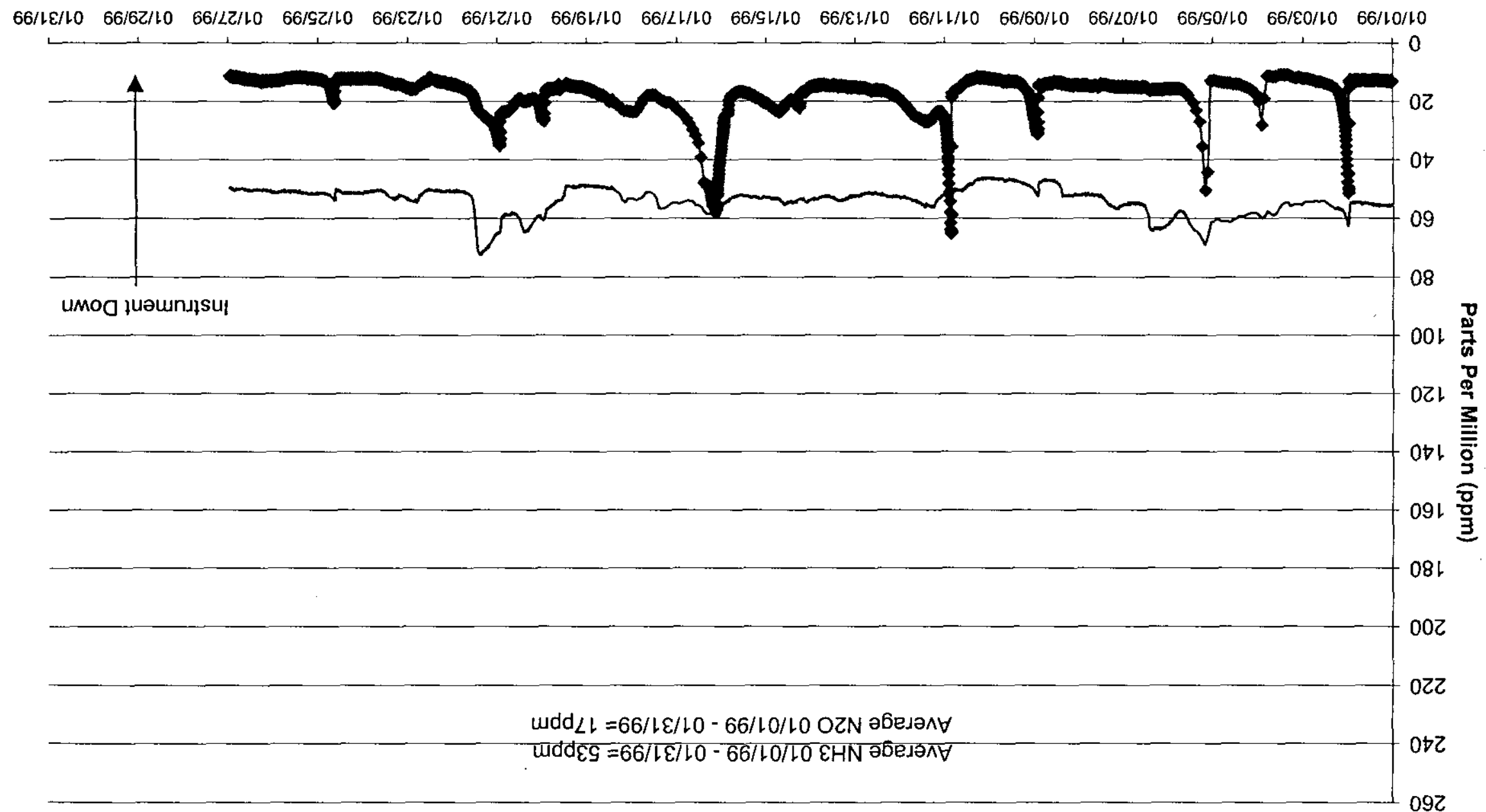

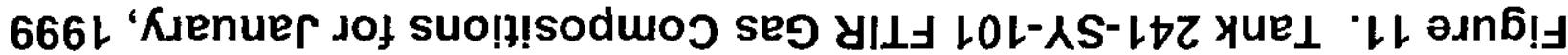


Figure 12. Tank 241-SY-101 FTIR Gas Compositions for February, 1999

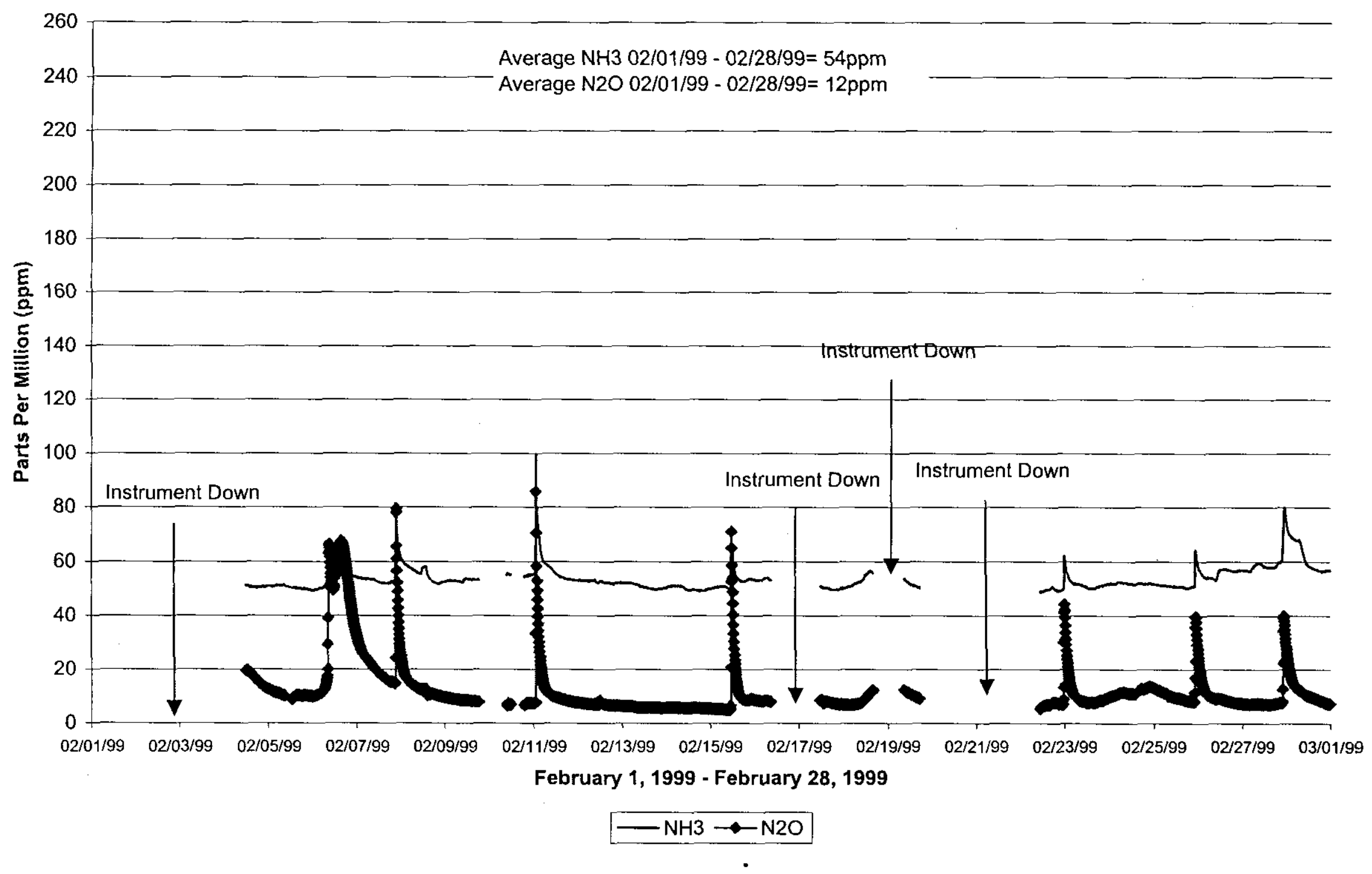


Figure 13. Tank 241-SY-101 FTIR Gas Compositions for March, 1999

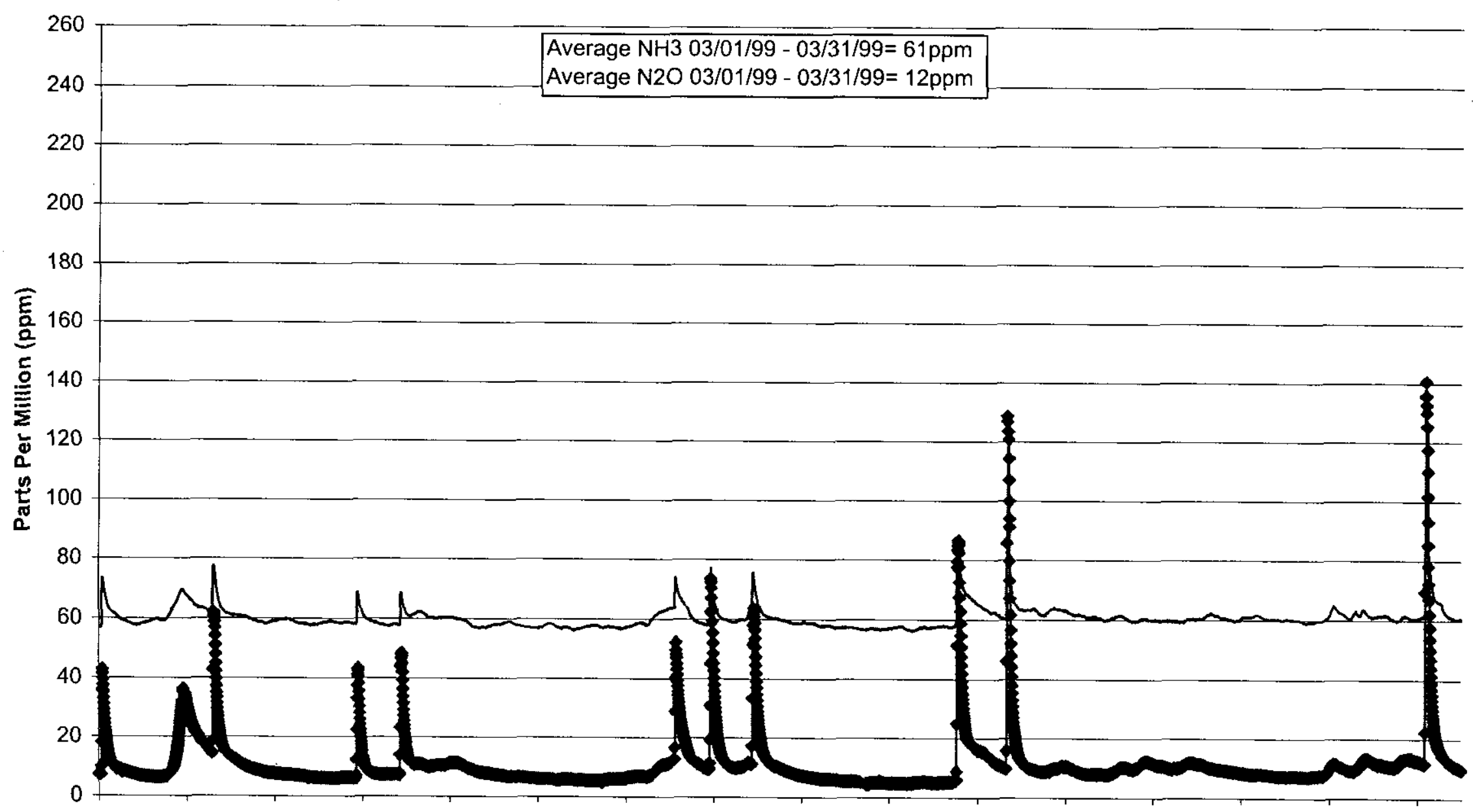

$\begin{array}{llllllllllllllll}03 / 01 / 99 & 03 / 03 / 99 & 03 / 05 / 99 & 03 / 07 / 99 & 03 / 09 / 99 & 03 / 11 / 99 & 03 / 13 / 99 & 03 / 15 / 99 & 03 / 17 / 99 & 03 / 19 / 99 & 03 / 21 / 99 & 03 / 23 / 99 & 03 / 25 / 99 & 03 / 27 / 99 & 03 / 29 / 99 & 03 / 31 / 99\end{array}$ March 1, 1999 - March 31, 1999

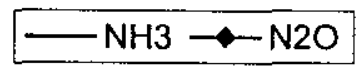


Figure 14. Tank 241-SY-101 Total Gas

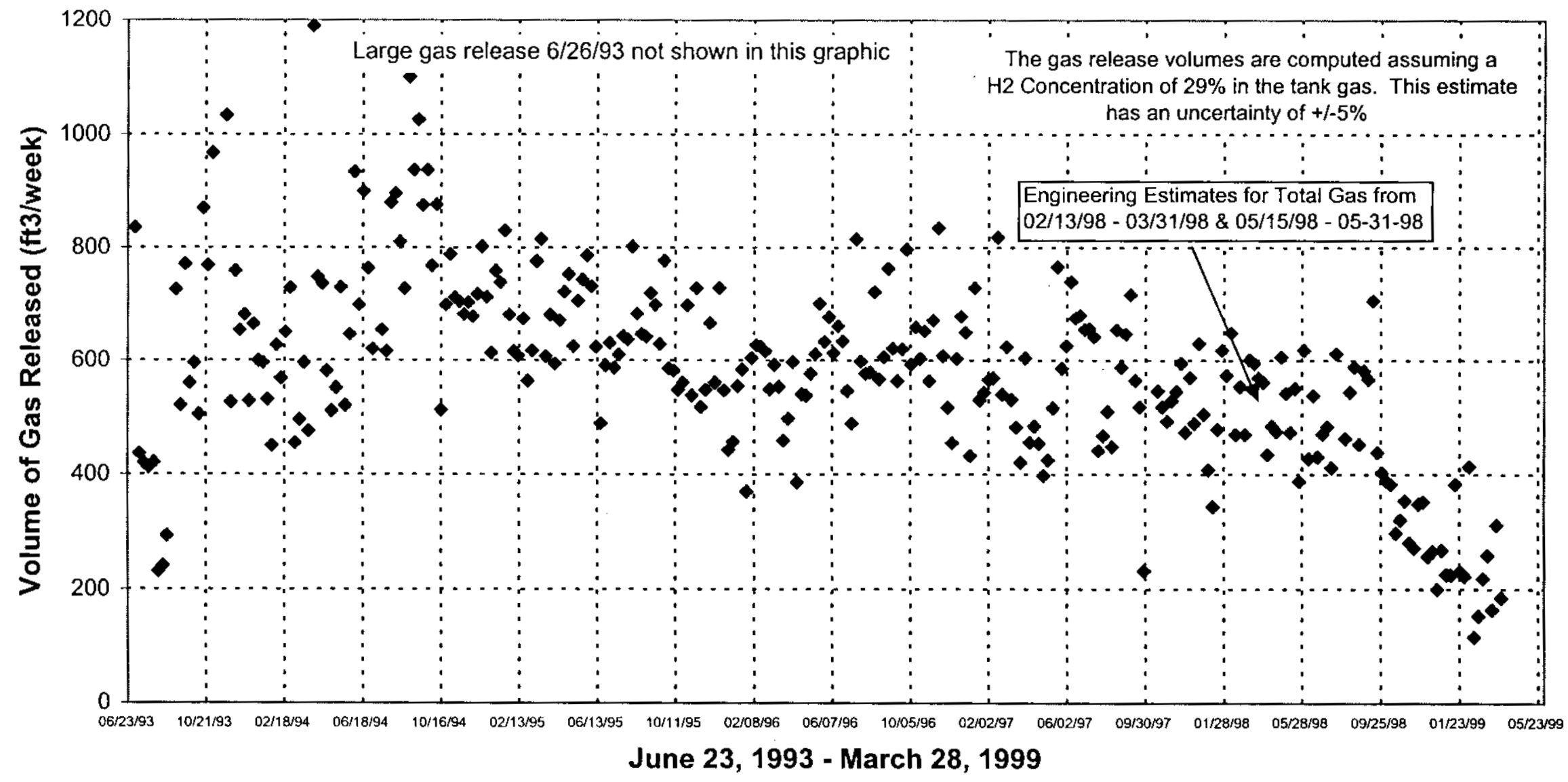

- Total Gas (ft3) 


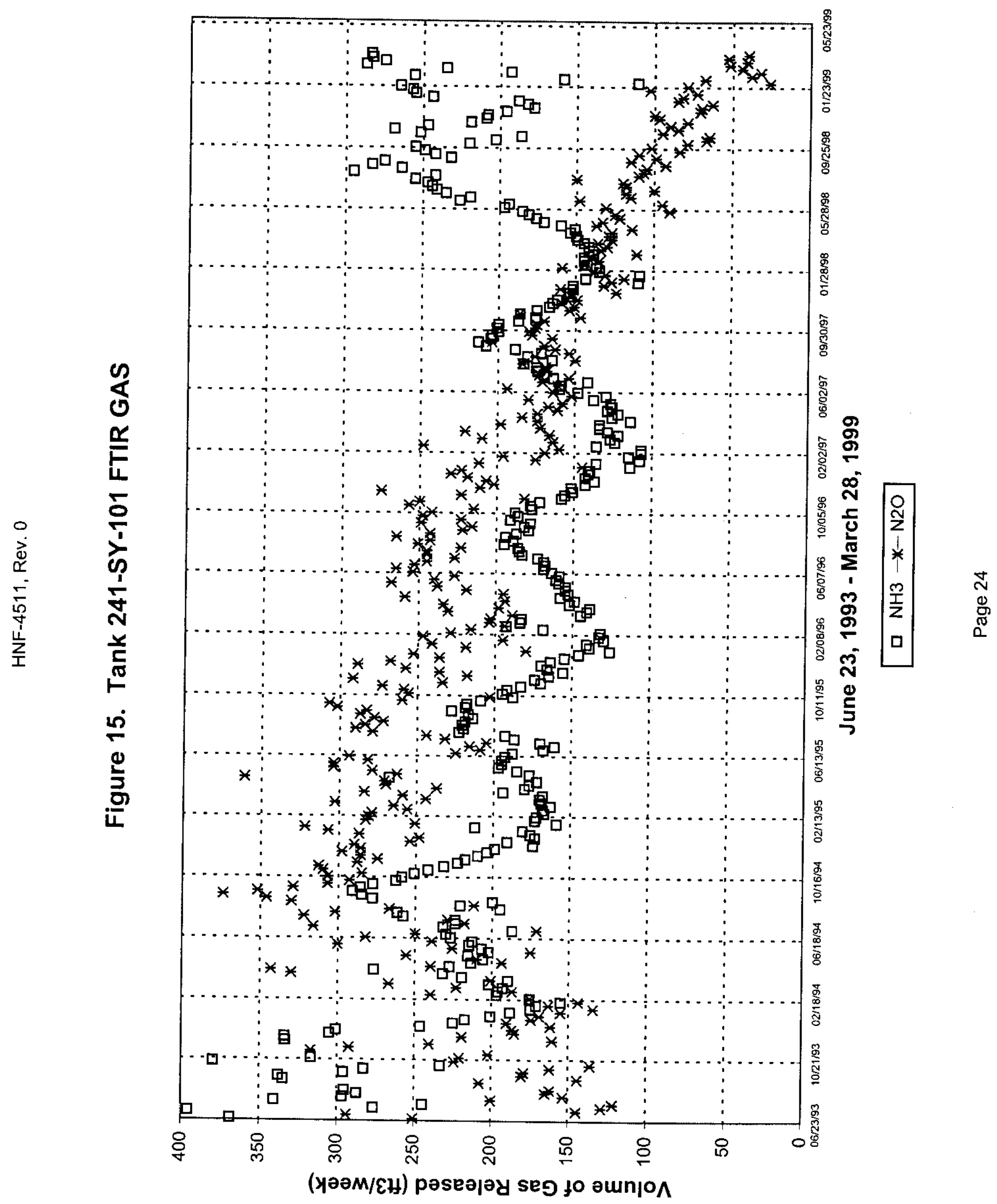


Figure 16. Tank 241-SY-101

Gas Concentrations - Wkly Avg. of H2

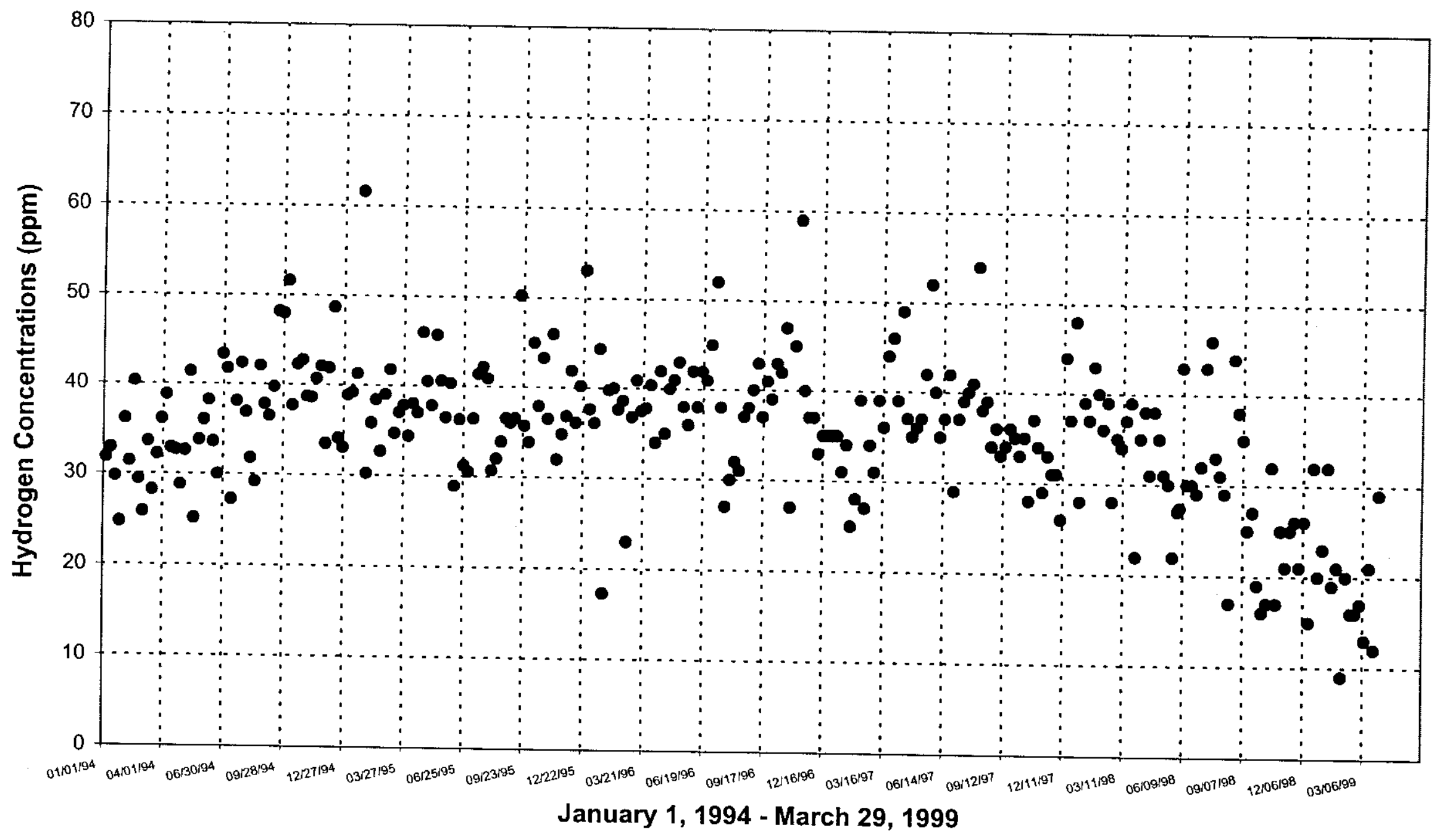




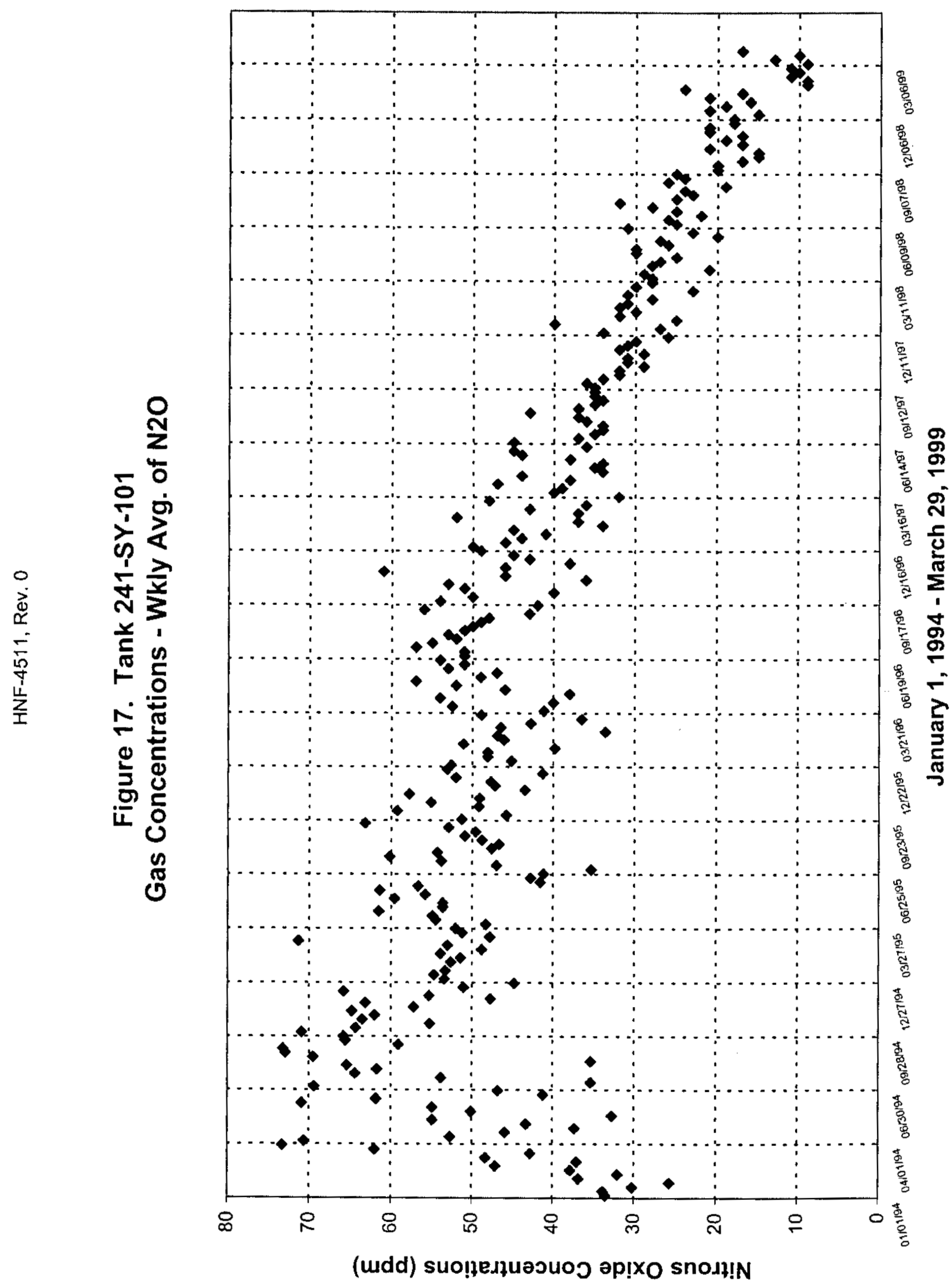

$\infty$
$\mathbb{N}$
$\Phi$
$\mathbb{0}$
0 


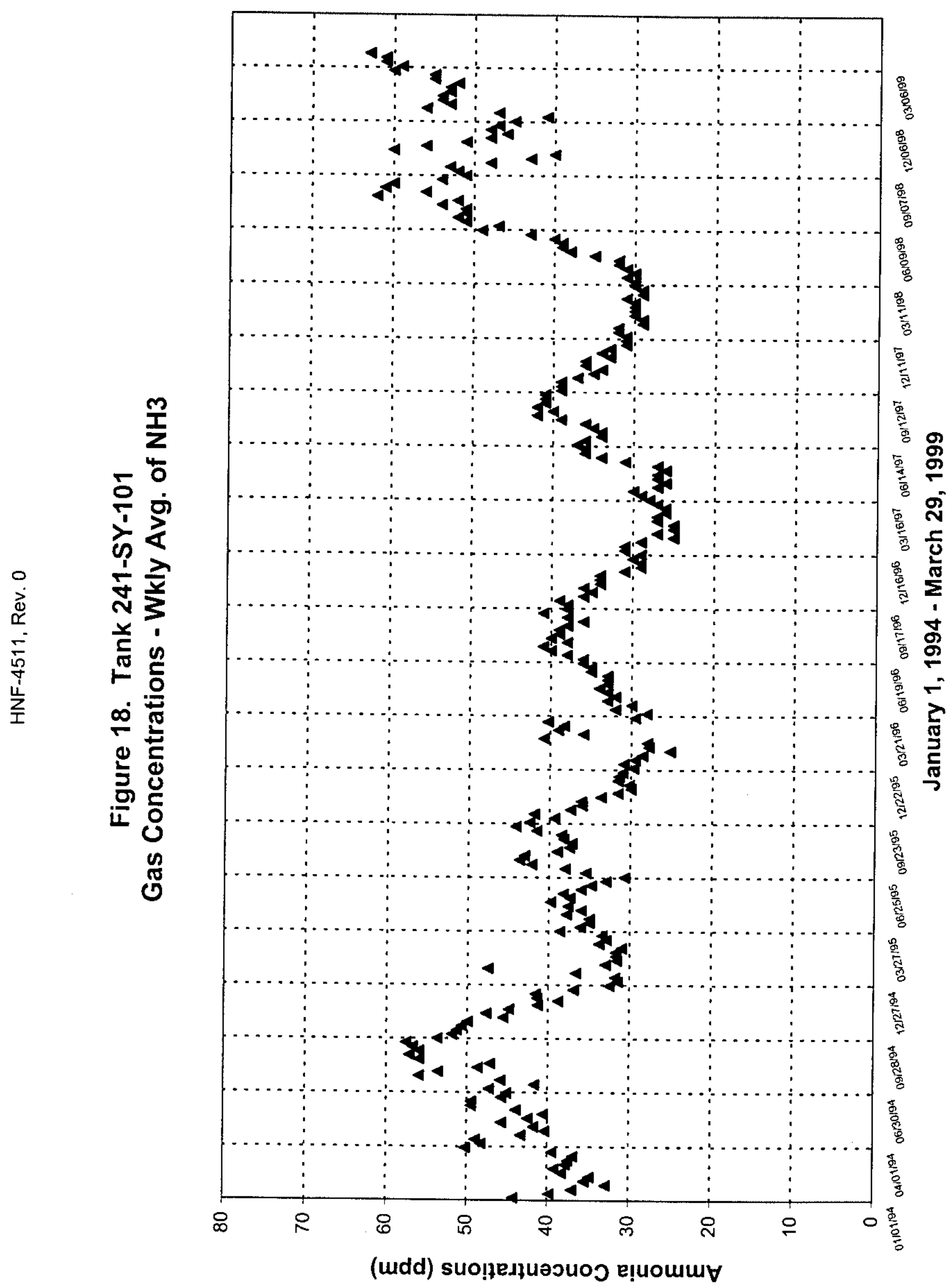

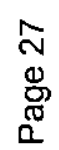


HNF-4511, Rev. 0

Figure 19
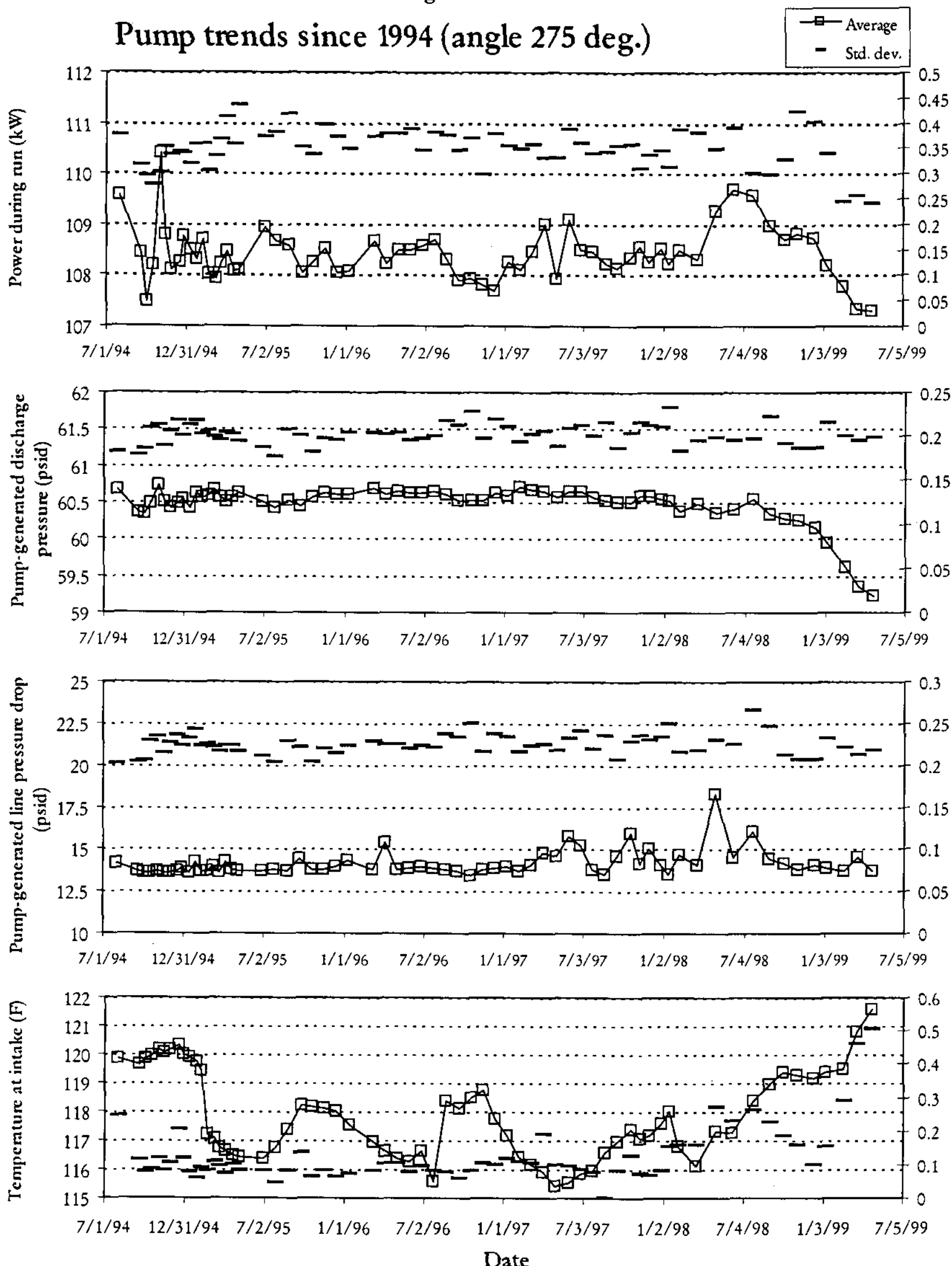
Figure 20. SY-101 Pressures at Mixer Pump Nozzles

Pump Run on 3/31/99 at 03:52

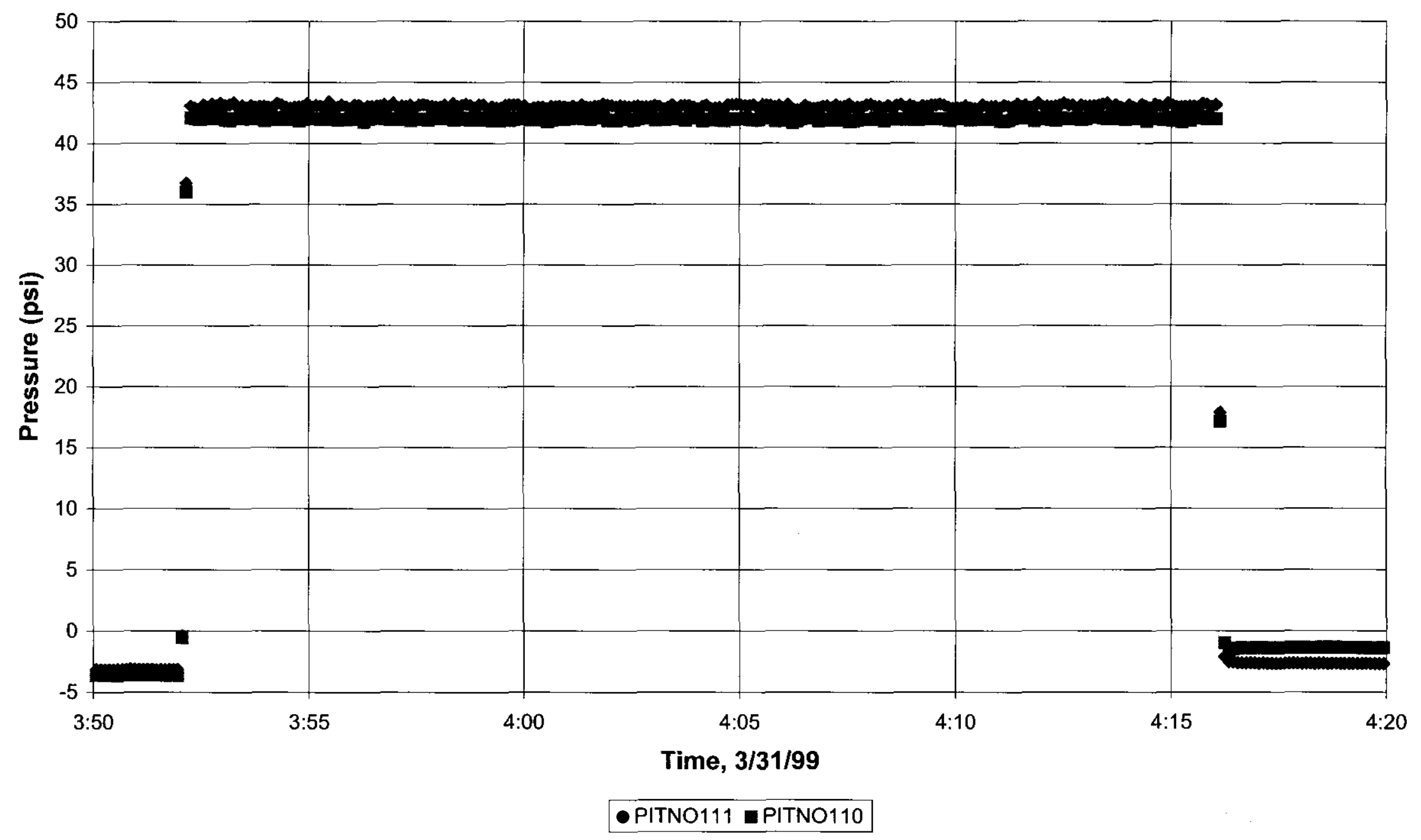

Page 29 
Figure 21. SY-101 Pressures at Mixer Pump Nozzles

Pump Run on 3/31/99 at 03:52

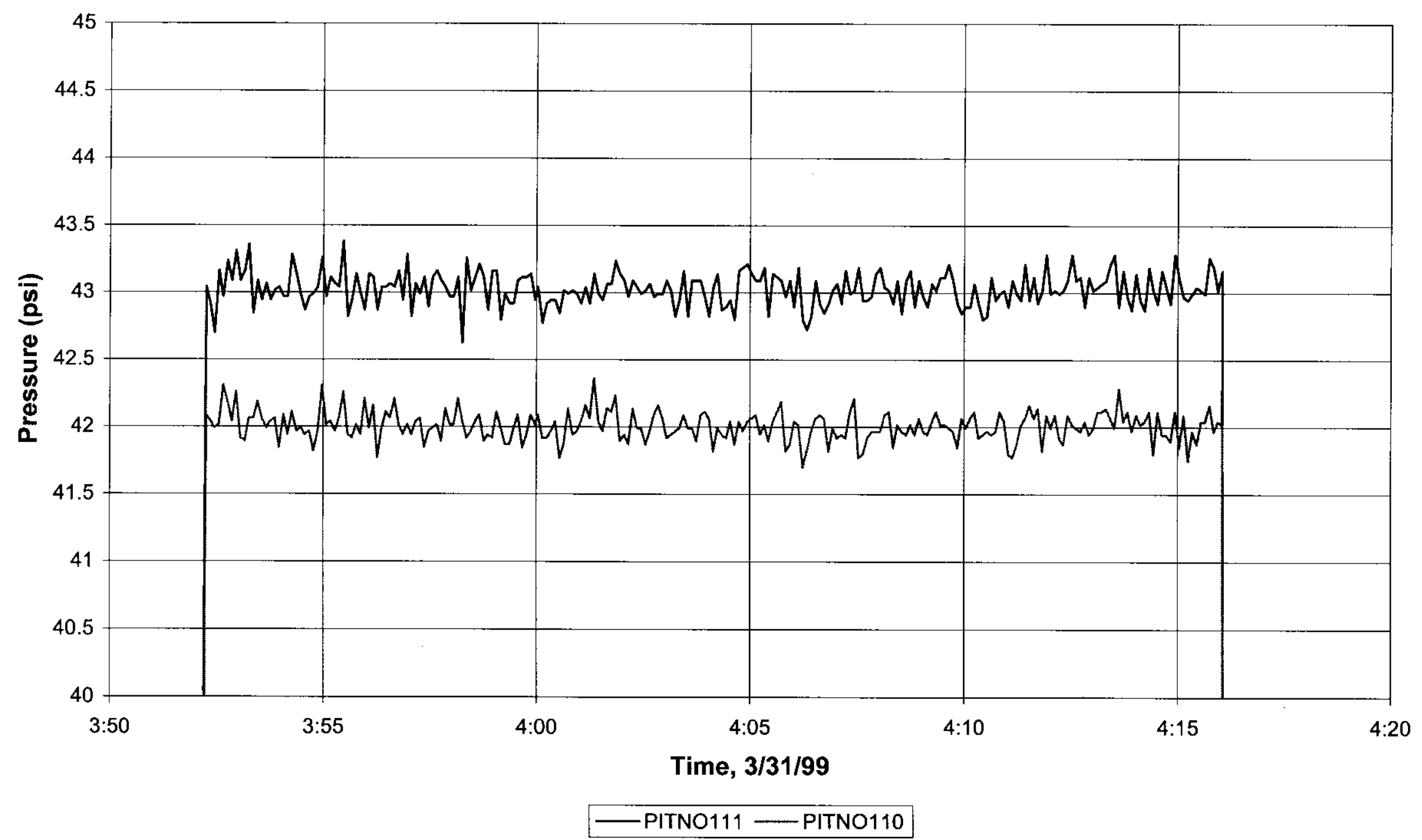

Page 30 


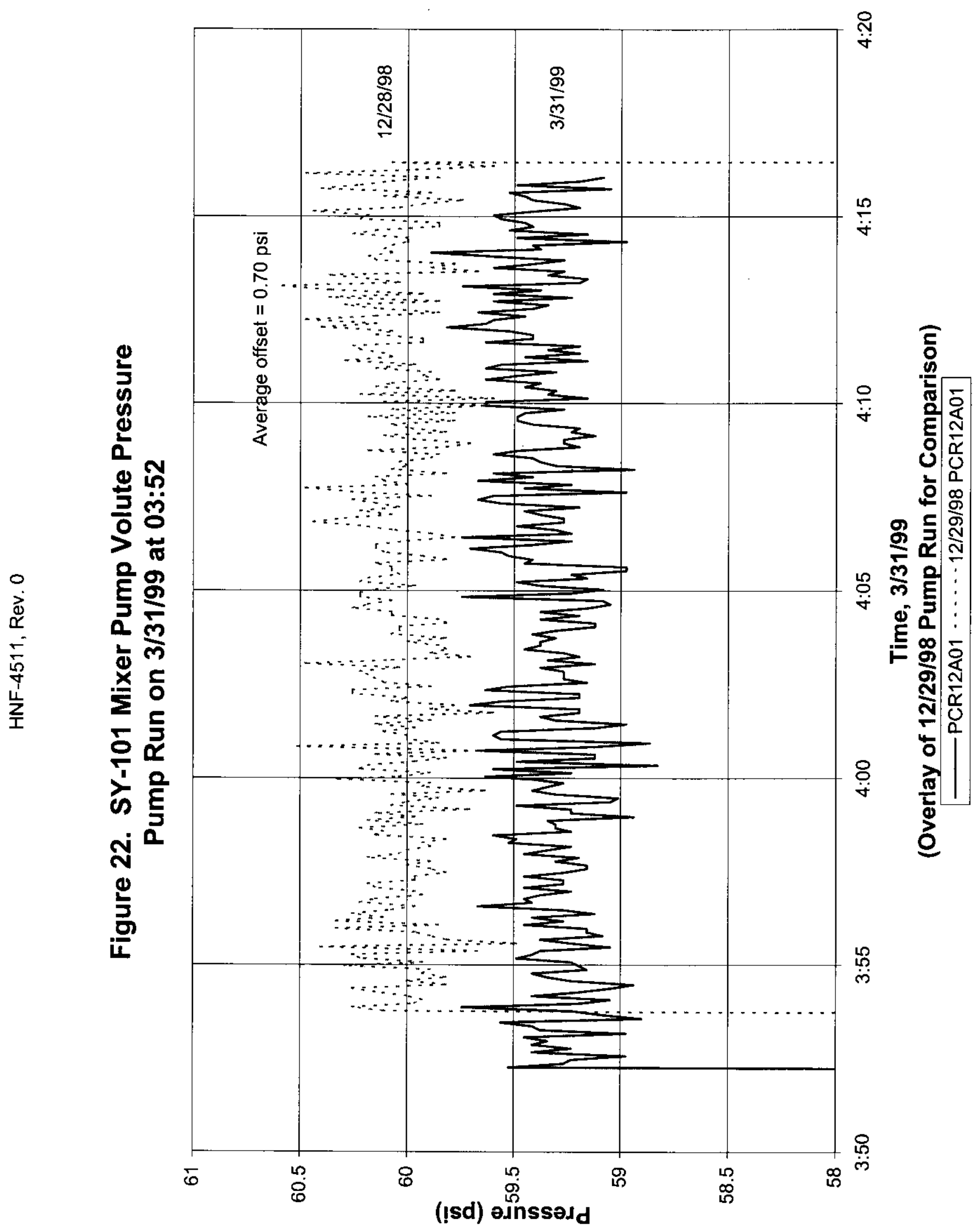




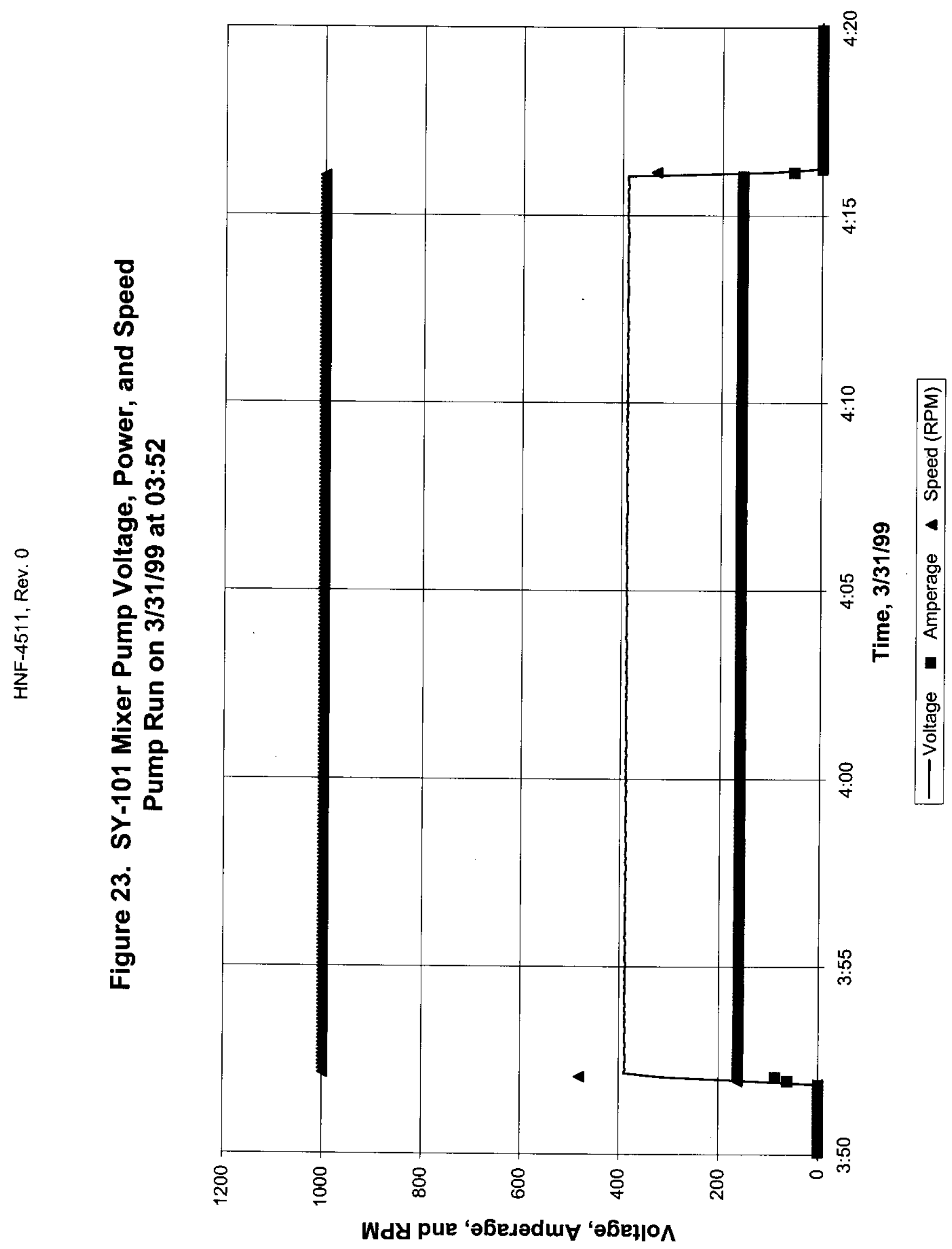


Figure 24. SY-101 Mixer Pump Power

Pump Run on 3/31/99 at 03:52

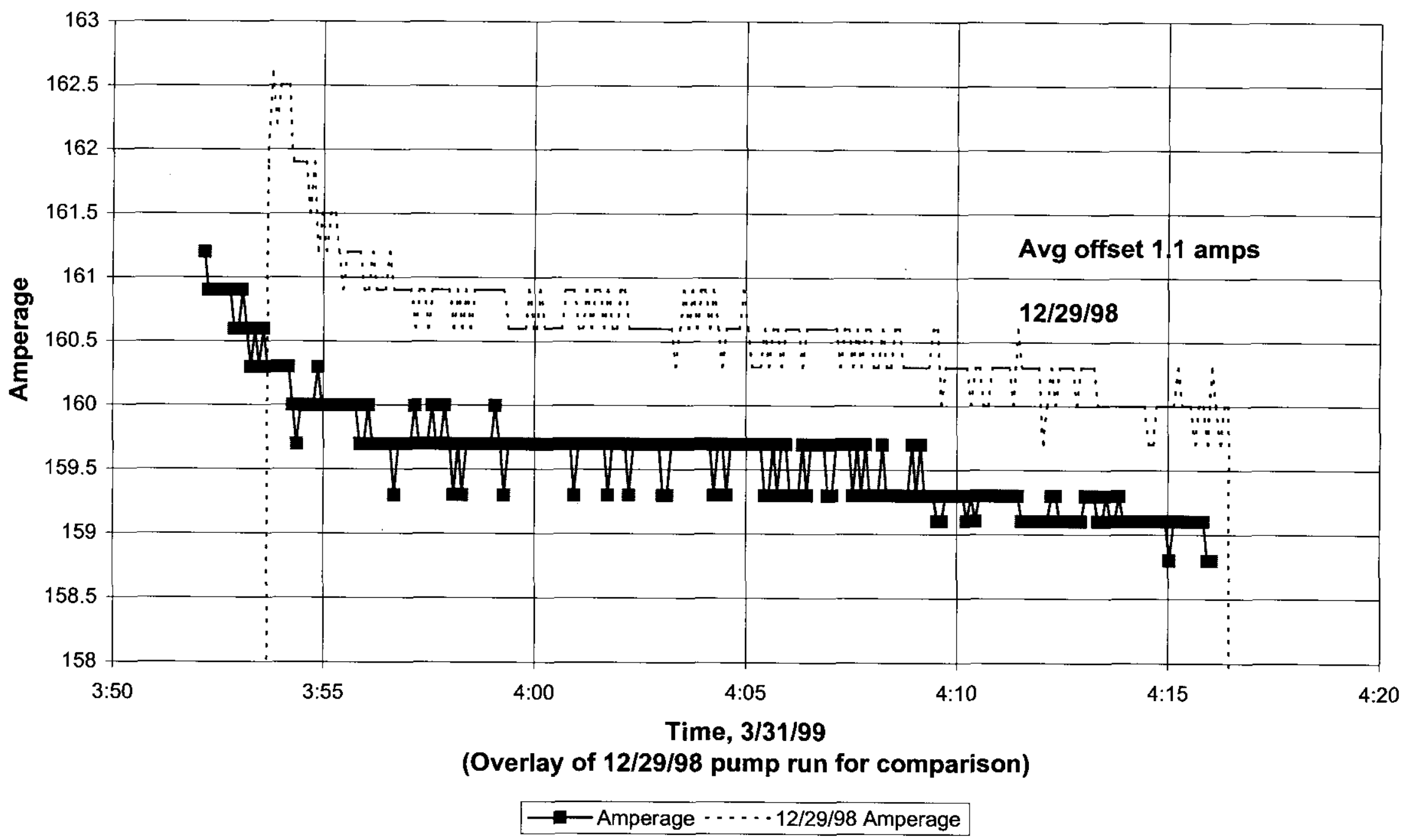




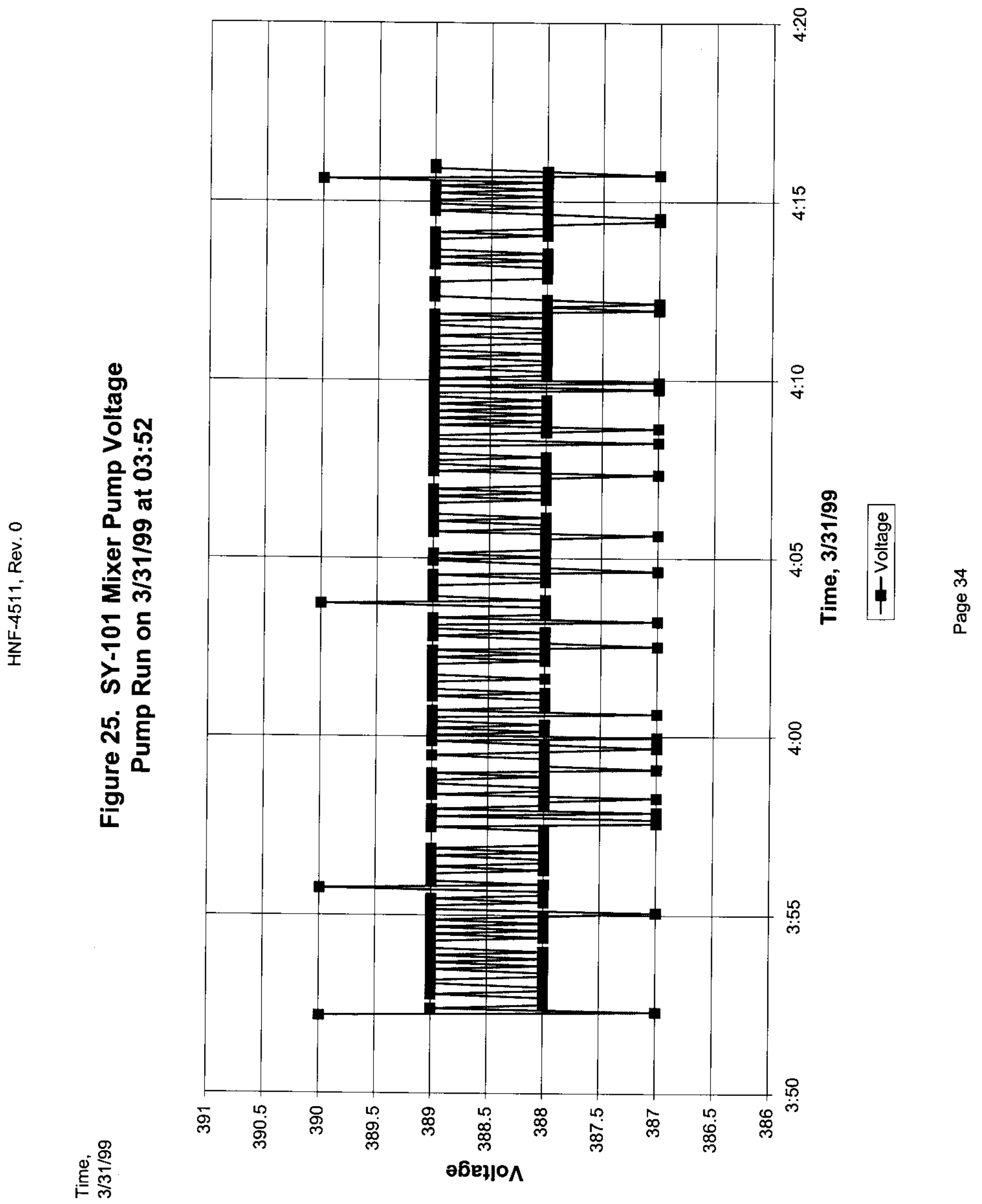


Figure 26. SY-101 Mixer Pump Speed

Pump Run on 3/31/99 at 03:52

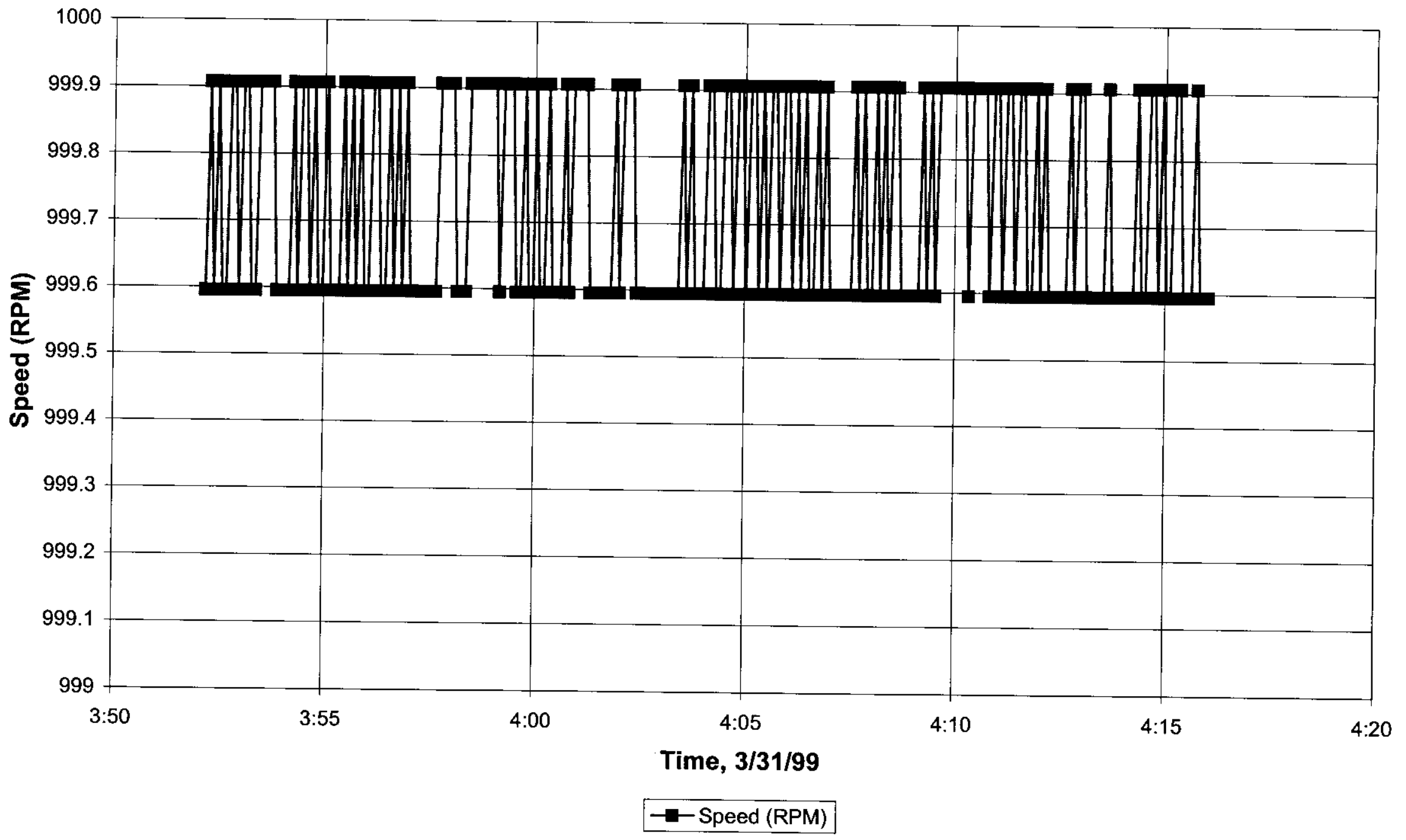

Page 35 


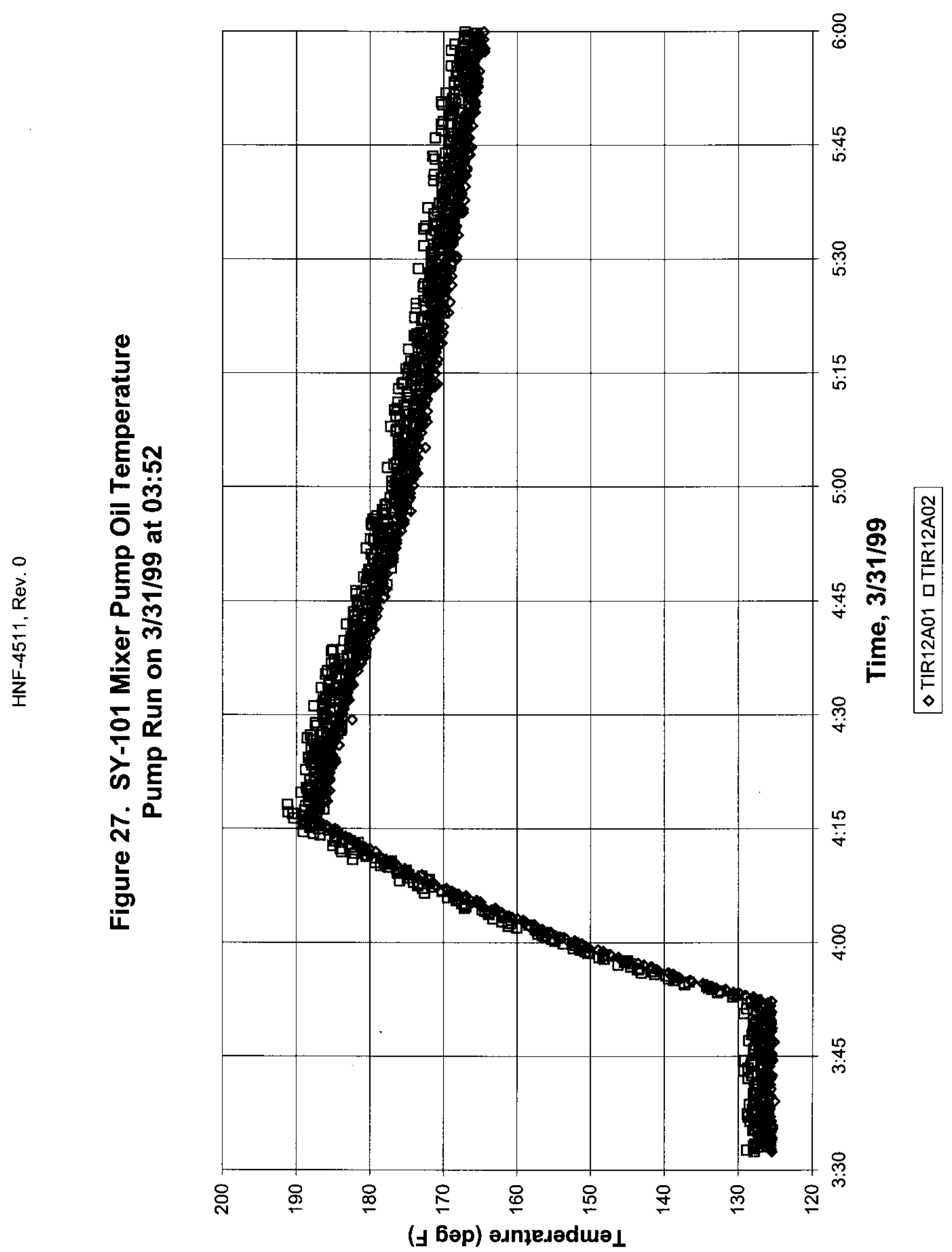




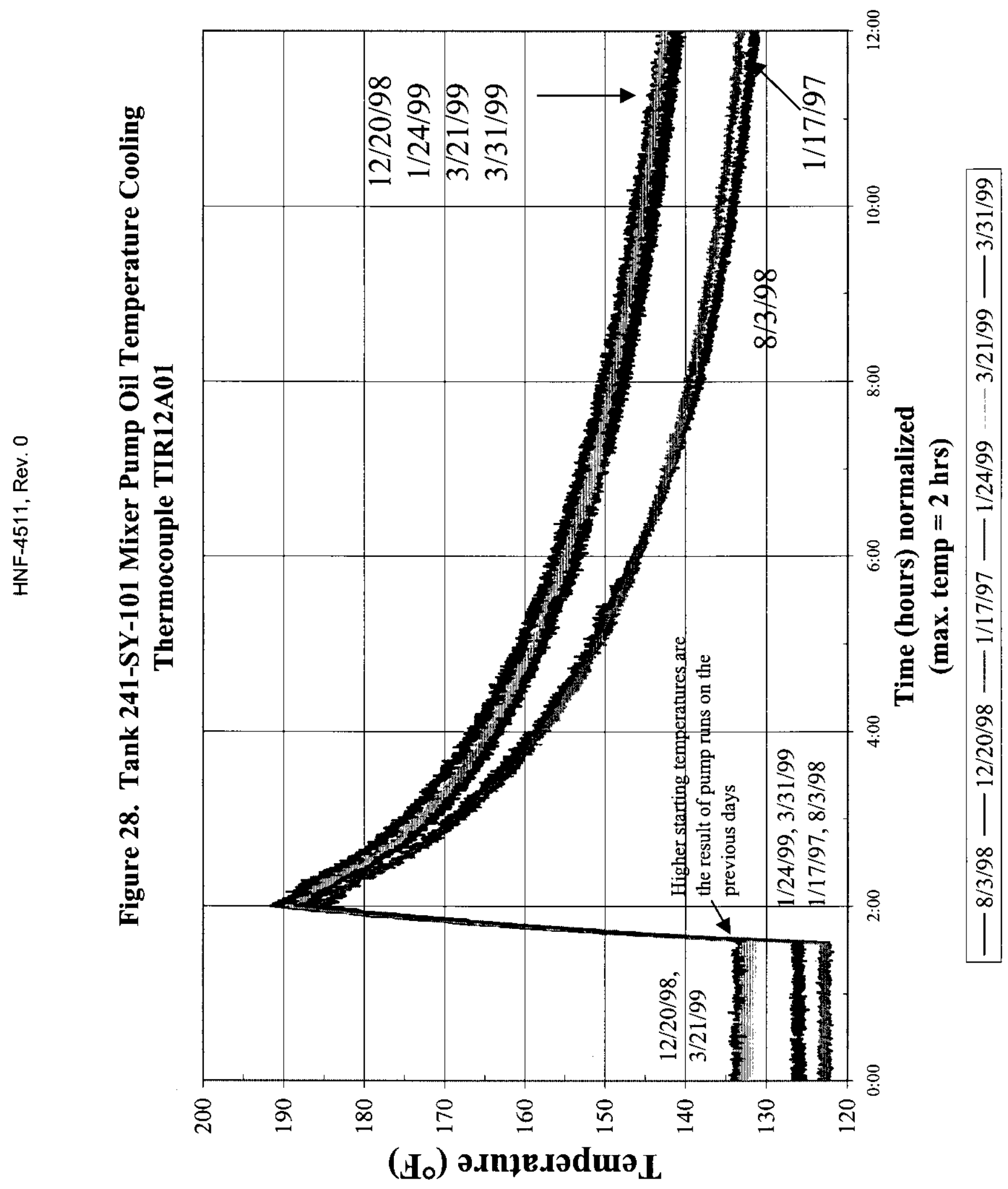

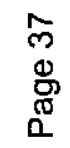


Figure 29. Bottom Thermocouple Responses at MIT 17B Pump Run on 3/21/99 (95 deg) at 15:36

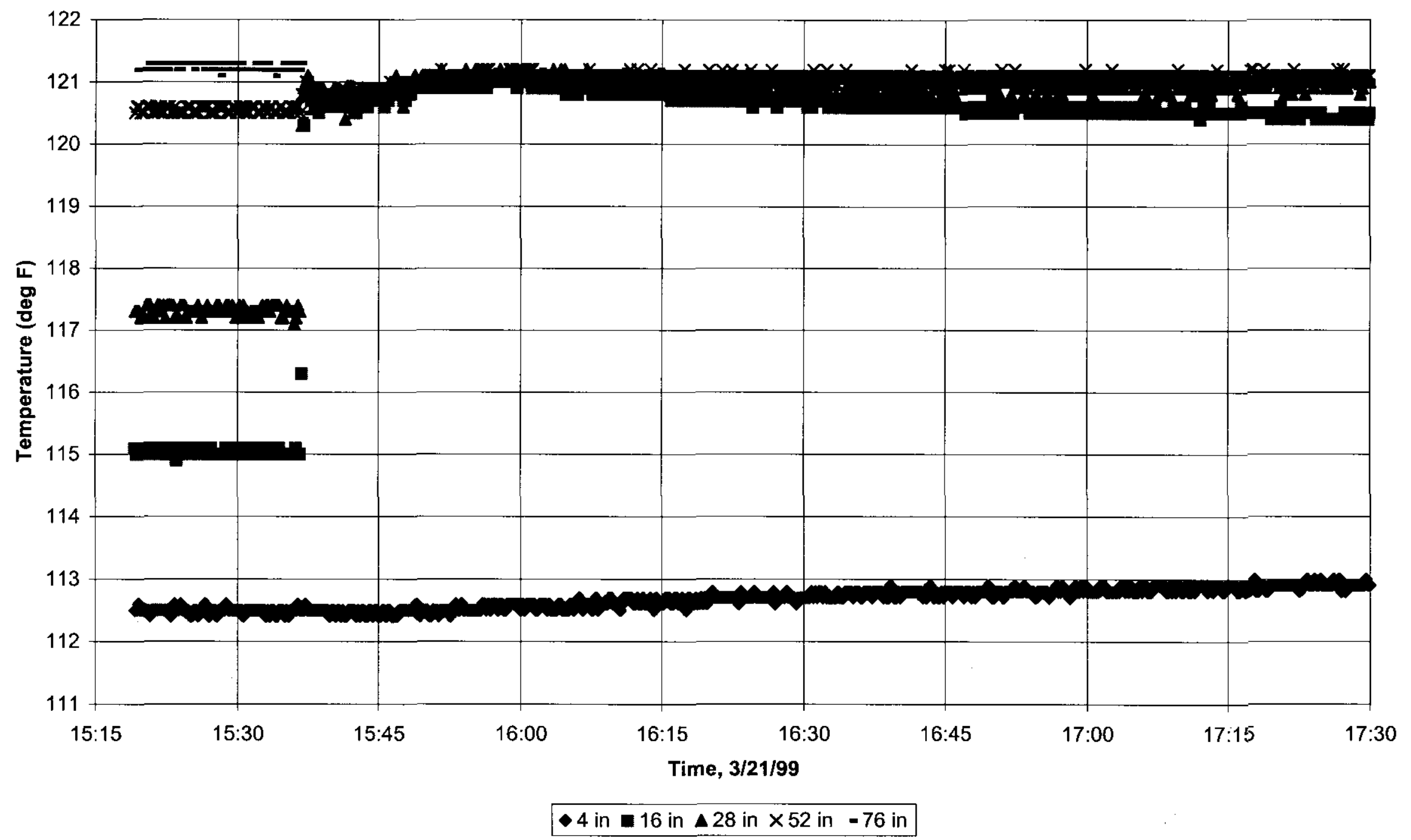

Page 38 


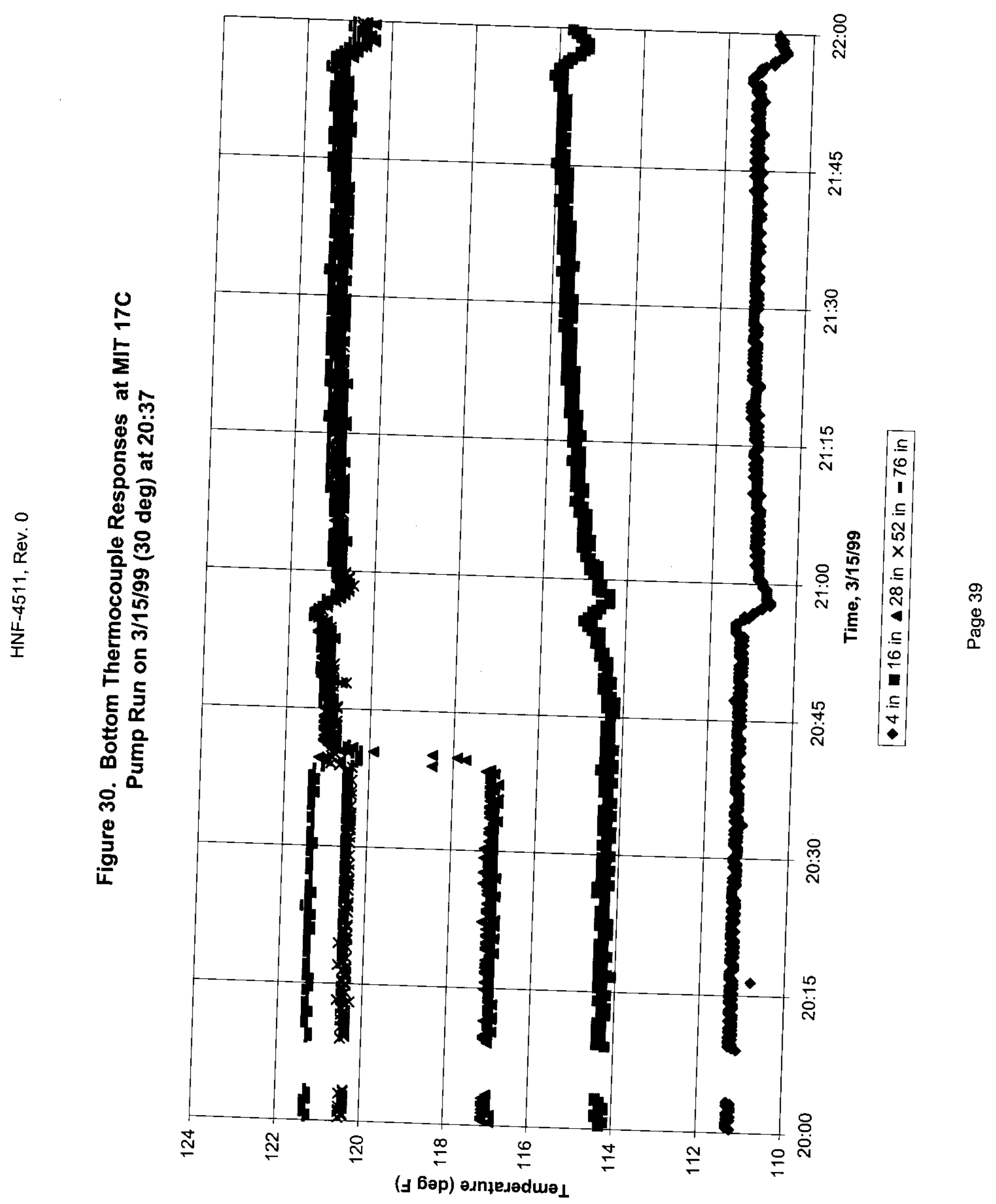


Figure 31. Tank 241-SY-101 Comparison of Temperature Validation Runs at MIT 17B

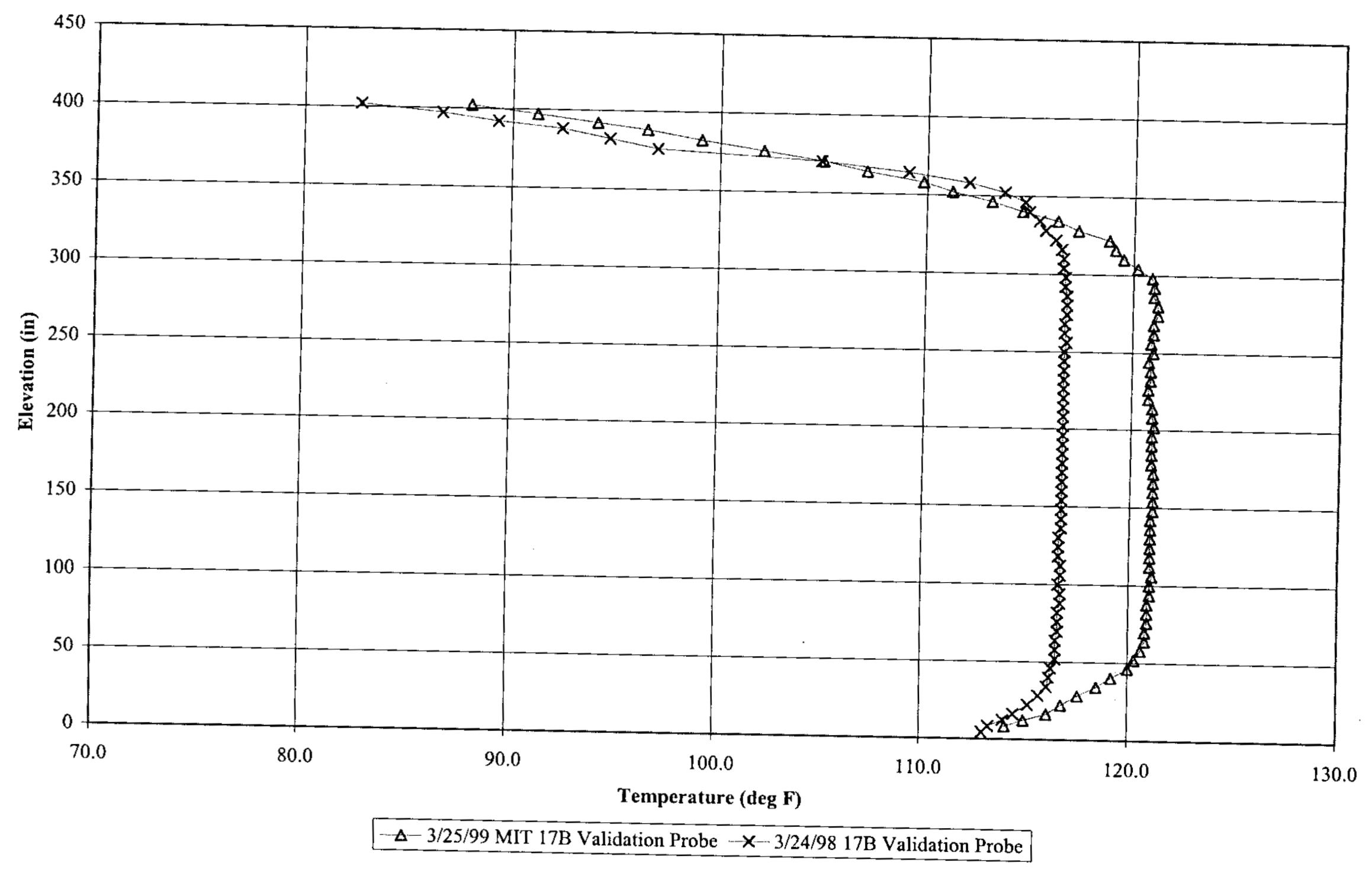


HNF-4511, Rev. 0

Figure 32. Tank SY-101 Concrete Temperature (Under Secondary Tank)

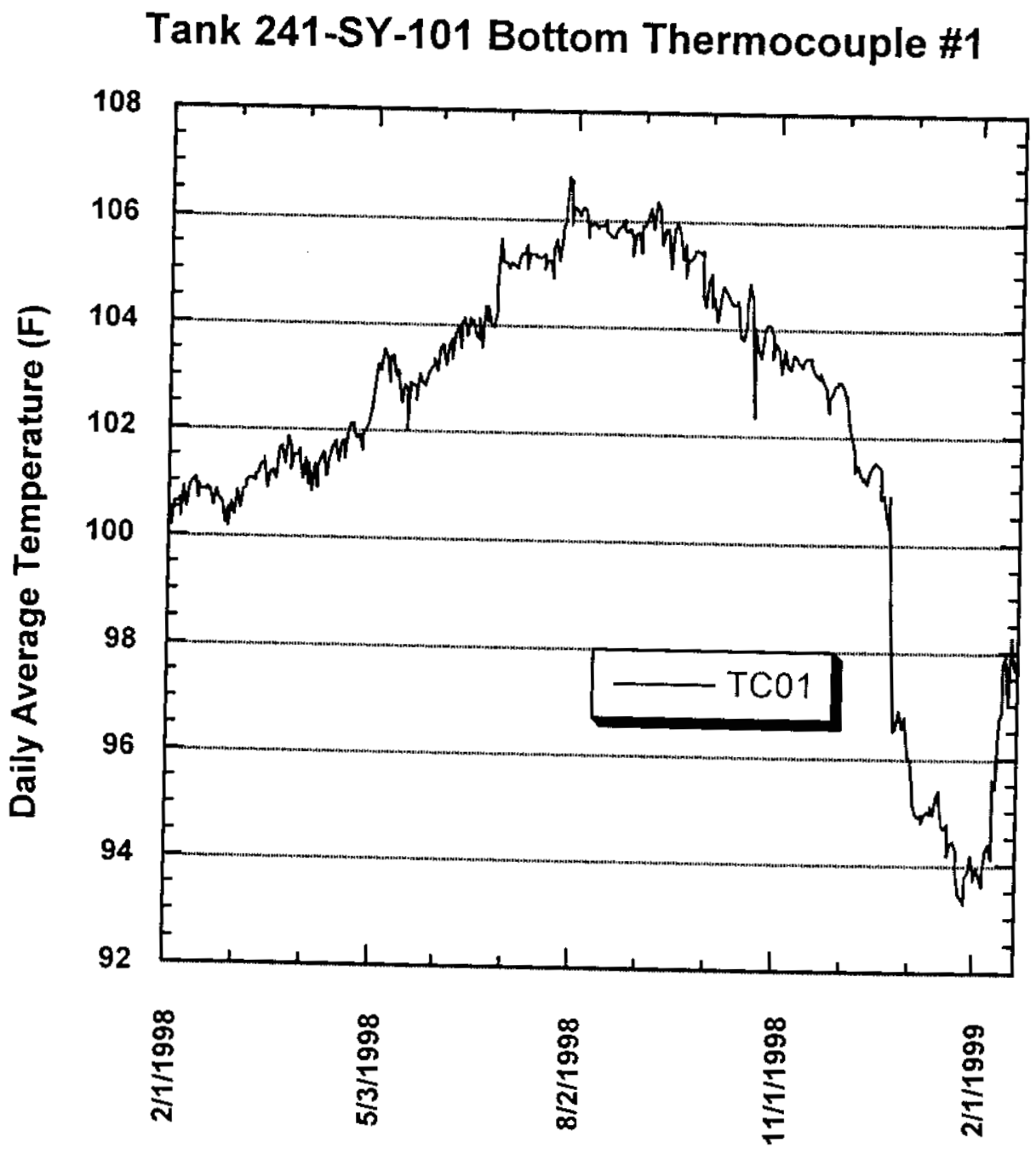




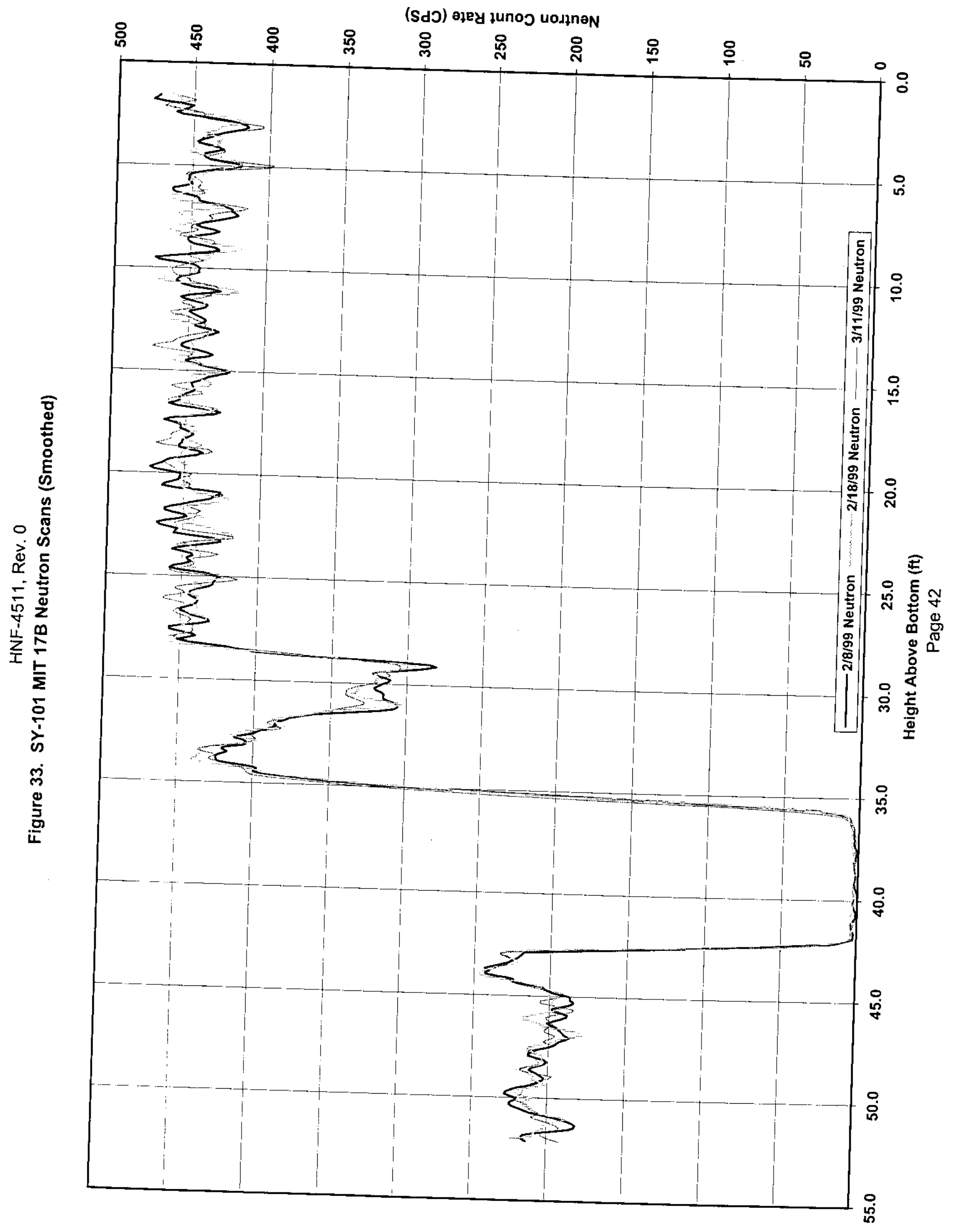


Figure 34. Tank 241-SY-101

Tank Pressure \& Vent Header Flow Rate

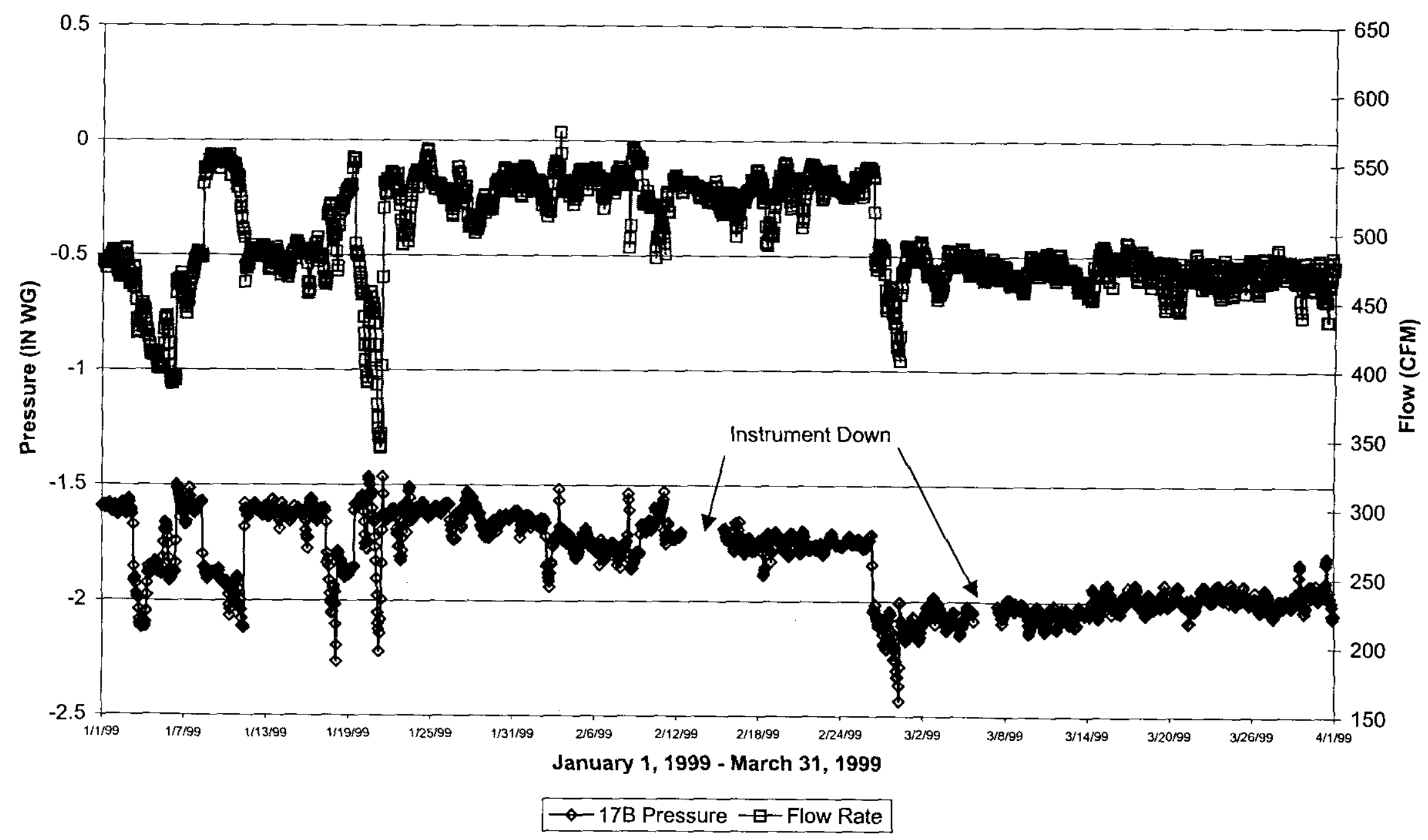




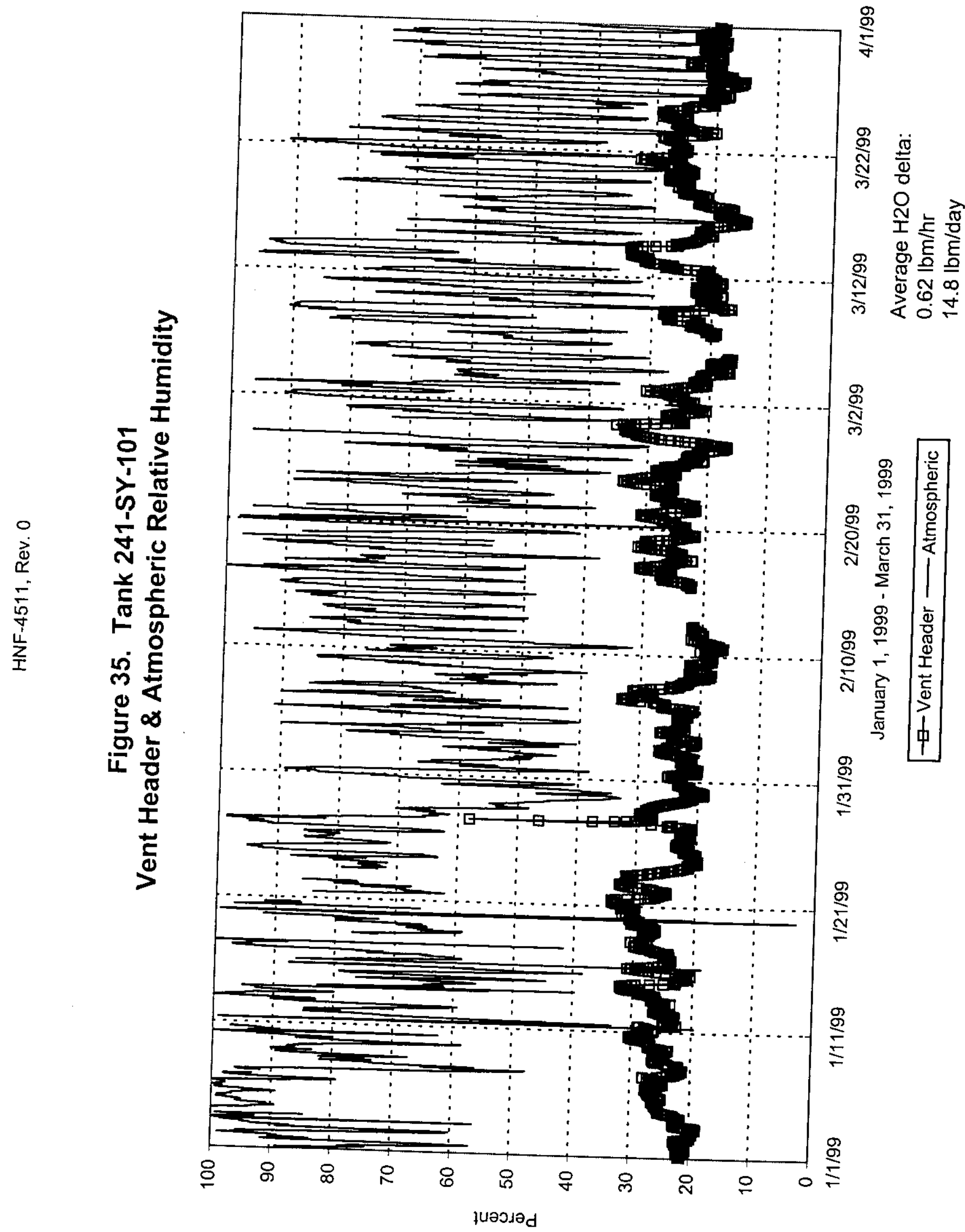


Figure 36. Tank 241-SY-101

Vent Header \& Atmospheric Temperatures

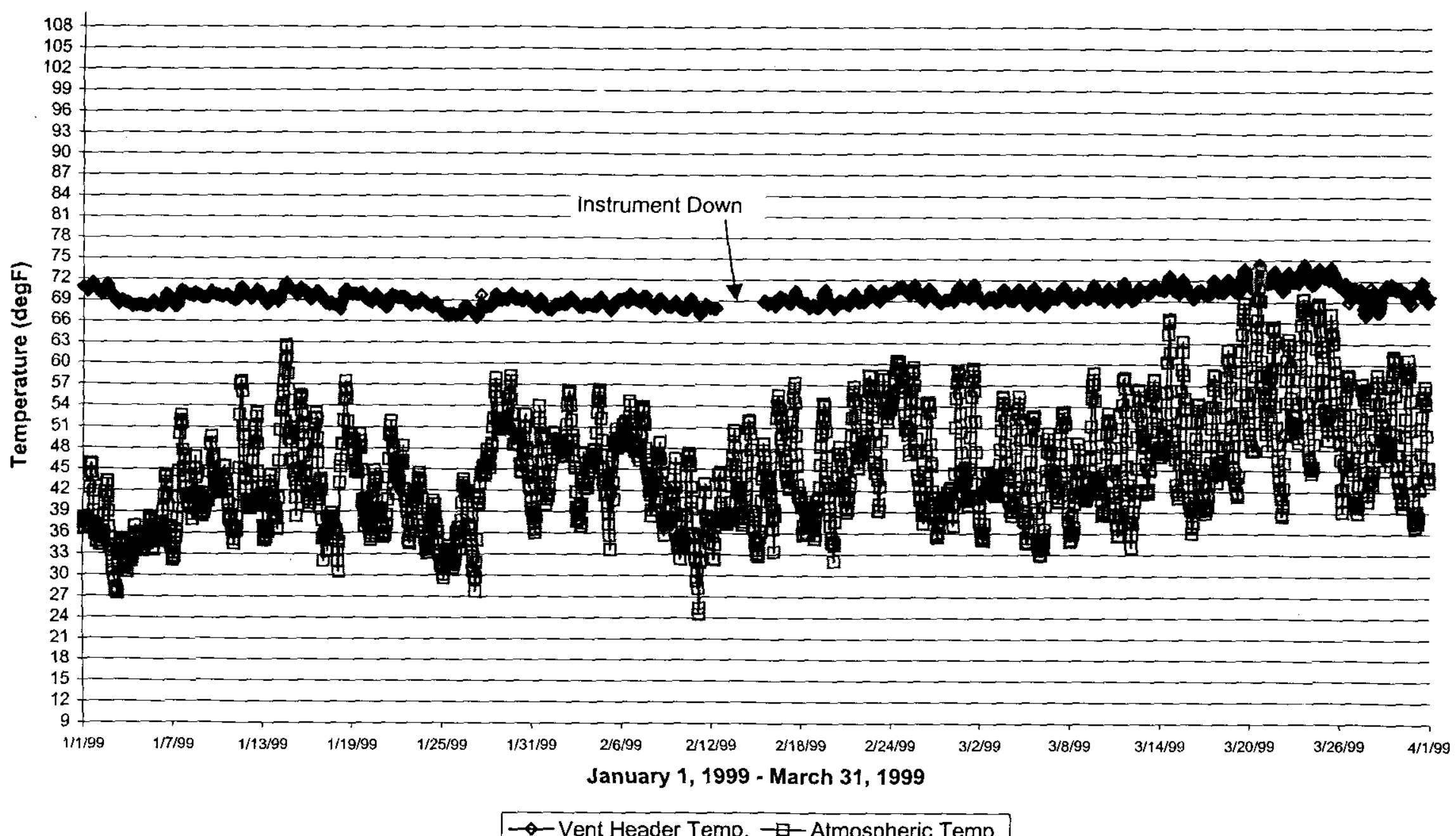


Figure 37. Tank 241-SY-101 1/Atm Pressure \& Surface Level

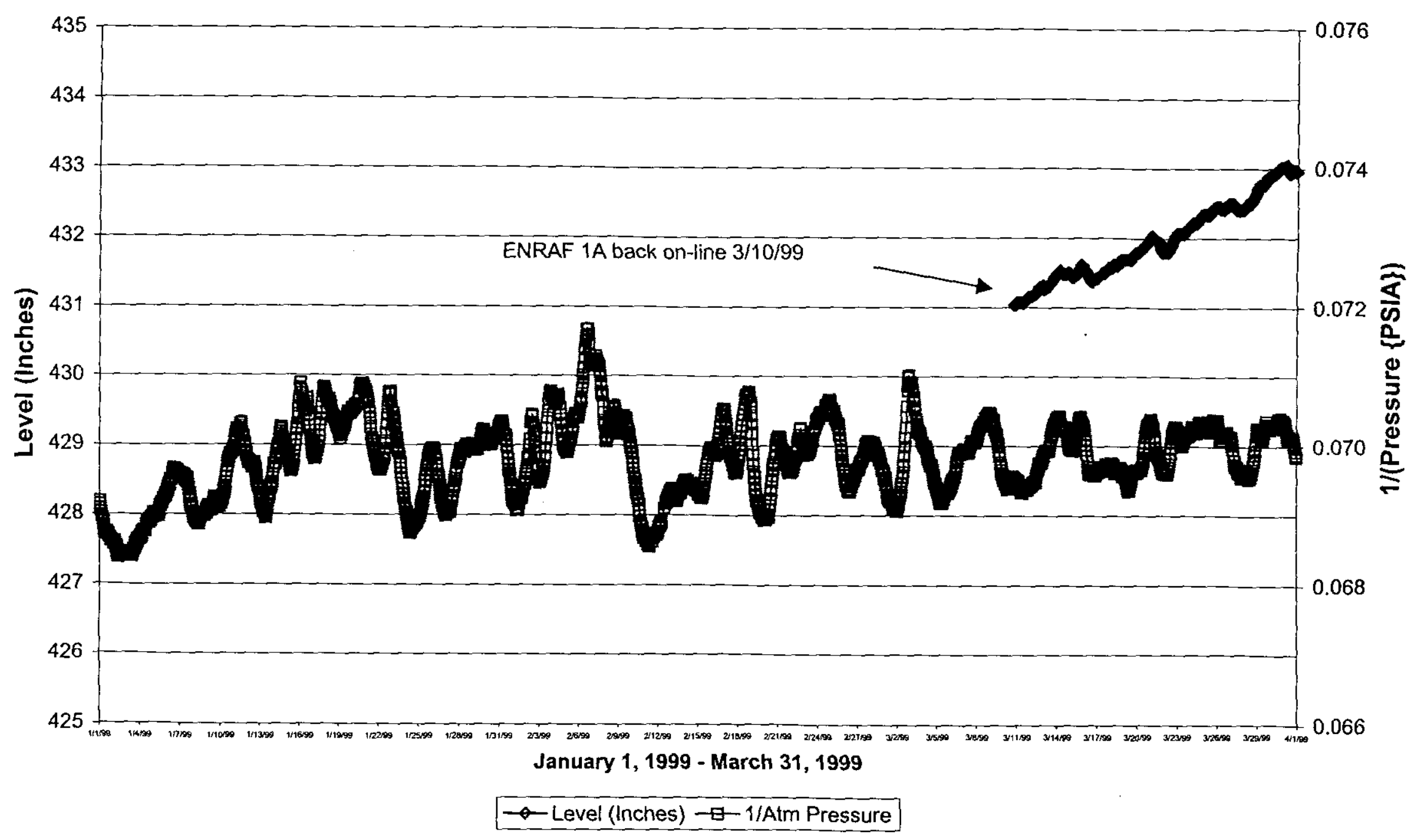




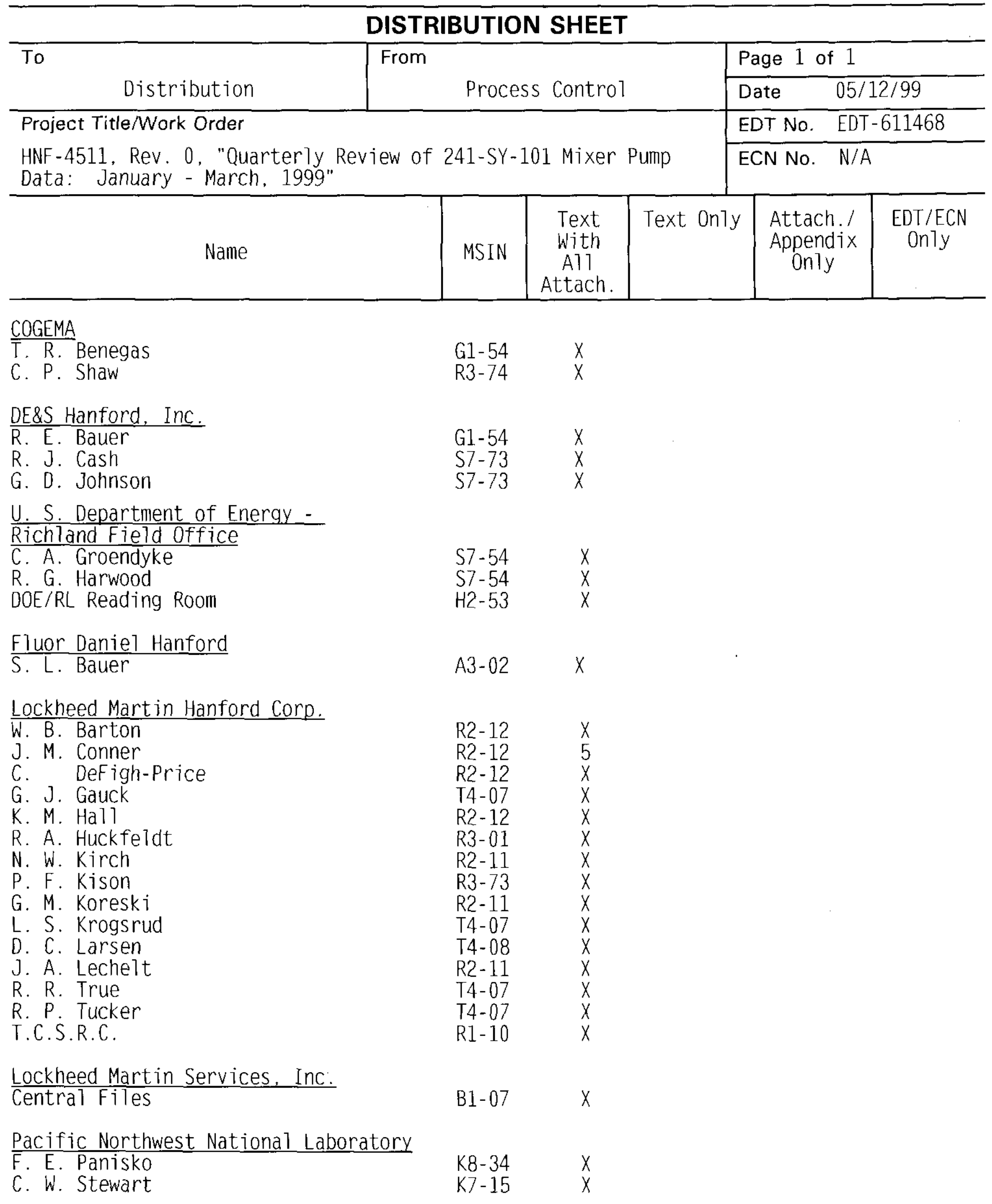

